\title{
Performance, feed utilization, and hepatic metabolic response of weaned juvenile Atlantic bluefin tuna (Thunnus thynnus L.): effects of dietary lipid level and source
}

\author{
Mónica B. Betancor (D) A Aurelio Ortega • Fernando de \\ la Gándara • Douglas R. Tocher • Gabriel Mourente
}

Received: 25 July 2018 / Accepted: 5 November 2018/Published online: 23 November 2018

(C) The Author(s) 2018

\begin{abstract}
Two trials were performed using extruded diets as on-growing feeds for weaned Atlantic bluefin tuna (Thunnus thynnus; ABT) to establish adequate dietary levels of both lipid and omega-3 long-chain polyunsaturated fatty acids (LC-PUFAs), and impacts on lipid metabolism via liver gene expression. In trial A, ABT were fed with either a commercial feed (Magokoro®; MGK) as a reference diet or two experimental feeds differing in lipid levels (15 or 20\%) using krill oil (KO) as the single lipid source in order to estimate suitable lipid content. Fish fed MGK displayed the highest growth, followed by $15 \mathrm{KO}$, and therefore a dietary lipid content of $15 \%$ was considered preferable to $20 \%$ at this stage. In trial B, fish were fed MGK, $15 \mathrm{KO}$, or a feed containing $15 \%$ lipid with a blend of $\mathrm{KO}$ and rapeseed oil (RO) $(1: 1, v / v ; 15 \mathrm{KORO})$. Fish fed $15 \mathrm{KO}$ and $15 \mathrm{KORO}$ showed no difference in weight
\end{abstract}

Electronic supplementary material The online version of this article (https://doi.org/10.1007/s10695-018-0587-9) contains supplementary material, which is available to authorized users.

M. B. Betancor $(\bowtie) \cdot$ D. R. Tocher

Institute of Aquaculture, Faculty of Natural Sciences, University of Stirling, Stirling, Scotland FK9 4LA, UK

e-mail: m.b.betancor@stir.ac.uk

A. Ortega $\cdot$ F. de la Gándara

Planta Experimental de Cultivos Marinos, Instituto Español de Oceanografía (IEO), 30860 Puerto de Mazarrón, Murcia, Spain

G. Mourente

Departamento de Biología, Facultad de Ciencias del Mar y Ambientales, Universidad de Cádiz, 11510 Puerto Real, Cádiz, Spain gain, specific growth rate, and fork length. Increasing dietary lipid level or including vegetable oil, RO, in the feeds did not increase liver lipid content. Liver fatty acid compositions largely reflected dietary profiles confirming very limited endogenous LC-PUFA biosynthesis. Liver of ABT fed $15 \mathrm{KO}$ and $20 \mathrm{KO}$ displayed the highest contents of docosahexaenoic acid (DHA). The hepatic expression of genes encoding enzymes and transcription factors involved in lipid and fatty acid metabolism, as well as genes encoding antioxidant enzymes, showed that many of these genes were regulated by dietary lipid and LC-PUFA content. Results suggested that ABT juveniles can be on-grown on inert dry feeds that support good fish growth and the accumulation of DHA.

Keywords Atlantic bluefin tuna - Dietary lipid content . Dietary lipid source $\cdot$ Production performance $\cdot$ Hepatic lipid metabolism $\cdot$ Gene expression

$\begin{array}{ll}\text { Abbreviations } \\ \text { ABT } & \text { Atlantic bluefin tuna } \\ \text { aco } & \text { Acyl coA oxidase } \\ \text { ARA } & \text { Arachidonic acid }(20: 4 \mathrm{n}-6) \\ \text { cat } & \text { Catalase } \\ \text { cpt1 } & \text { Carnitine palmitoyl transferase I } \\ \text { dah } & \text { Days after hatch } \\ \text { DHA } & \text { Docosahexaenoic acid (22:6n-3) } \\ \text { EFA } & \text { Essential fatty acid } \\ \text { EPA } & \text { Eicosapentaenoic acid (20:5n-3) } \\ \text { elovl5 } & \text { Fatty acyl elongase 5 } \\ \text { fabp2 } & \text { Fatty acid binding protein 2 (intestinal) }\end{array}$




$\begin{array}{ll}\text { fabp4 } & \text { Fatty acid binding protein } 4 \text { (adipocyte) } \\ \text { fabp7 } & \text { Fatty acid binding protein } 7 \text { (brain-type) } \\ \text { fads2d6 } & \text { Delta-6 fatty acyl desaturase } \\ \text { fas } & \text { Fatty acid synthase } \\ \text { gpx1 } & \text { Glutathione peroxidase 1 } \\ \text { gpx4 } & \text { Glutathione peroxidase } 4 \\ \text { hmgcl } & \text { 3-Hydroxy-3-methylglutaryl-CoA lyase } \\ \text { LA } & \text { Linoleic acid (18:2n-6) } \\ \text { LC-PUFA } & \text { Long-chain polyunsaturated } \\ & \text { fatty acid } \\ \text { LNA } & \alpha \text {-Linolenic acid (18:3n-3) } \\ \text { lpl } & \text { Lipoprotein lipase } \\ \text { lxr } & \text { Liver X receptor } \\ \text { MUFA } & \text { Monounsaturated fatty acid } \\ \text { ppard } & \text { Peroxisome proliferator-activated } \\ & \text { receptor alpha } \\ \text { ppary } & \text { Peroxisome proliferator-activated } \\ & \text { receptor gamma } \\ \text { PUFA } & \text { Polyunsaturated fatty acid } \\ r x r & \text { Retinoid X receptor } \\ \text { SFA } & \text { Saturated fatty acid } \\ \text { sod } & \text { Superoxide dismutase } \\ \text { srebp1 } & \text { Sterol regulatory element-binding } \\ & \text { protein 1 } \\ \text { srebp2 } & \text { Sterol regulatory element-binding } \\ & \text { protein 2 } \\ & \end{array}$

\section{Introduction}

Currently, the vast majority of Atlantic bluefin tuna (ABT) production from aquaculture is derived from fattening operations based in the Mediterranean Sea with the three main producer countries being Spain, Croatia, and Malta (Benetti et al. 2016; van Beijnen 2017). Essentially, captured wild ABT (mostly adult broodstock fish and some juveniles) are towed in sea pens to fattening farms where they are fed mainly on baitfish of variable quality (Benetti et al. 2016; van Beijnen 2017). The development of formulated sustainable feed is essential for the farming of tuna species, whether in fattening or, ultimately, closed life-cycle culture (van Beijnen 2017). The advantages of formulated diets include choice of the most nutritionally adequate ingredients, range of pellet size and consistent nutritional content, and reduced need for live feeds for larvae, and baitfish for hatchery-reared juveniles from 4 weeks after hatch onwards and, thus, the prevention of pathogen transmission. The development of artificial diets for Pacific bluefin tuna (Thunnus orientalis) (PBT) has been carried out extensively in Japan since 1995 (Kenji 2012) but, until recently, similar research has not been possible with Atlantic bluefin tuna (ABT; Thunnus thynnus L.) (Mourente and Tocher 2003, 2009). Biswas et al. (2009) concluded that a formulated diet with $62 \%$ crude protein and $18 \%$ crude lipid could ensure good growth in PBT juveniles. Subsequently, formulated diets for rearing juvenile PBT, including nutrient sources and requirements for crude protein, lipids, carbohydrates, and vitamin $\mathrm{C}$, were established (Biswas 2010; Biswas et al. 2016). Moreover, the partial or full replacement of fish oil (FO) sources with soybean oil (SO) for this species was also investigated (Biswas et al. 2011).

It is well known that lipid is required in the diet of fish to supply both metabolic energy and key nutrients such as essential fatty acids (EFAs) (Sargent et al. 2002). Appropriate uptake, assimilation, and accumulation of lipids improves growth and survival of all fish, but is particularly important in highly active migratory predator fish species such as tunas (Mourente and Tocher 2003, 2009). Additionally, omega-3 ( $n-3)$ long-chain polyunsaturated fatty acids (LC-PUFAs; $\geq 20$ carbons and $\geq 3$ double bonds), such as eicosapentaenoic acid (EPA; 20:5n-3) and docosahexaenoic acid (DHA; 22:6n-3), are required by most marine fish and are EFA for survival, normal growth, and development (Tocher 2010). The tendency nowadays regarding the formulation of aquafeeds is the replacement of marine ingredients with more sustainable raw materials such as plant proteins and vegetable oils of agricultural origin. Such terrestrial ingredients are devoid of EPA and DHA, making fish fed sustainable feeds dependent on endogenous production of $n-3$ LC-PUFA via metabolic biosynthesis pathways and the expression of key enzymes including fatty acyl desaturases (Fads) and elongases of very long-chain fatty acids (Elovl) (Tocher 2010; Betancor et al. 2015a). However, the capacity for the biosynthesis of EPA and DHA is very limited in bluefin tuna species (Gregory et al. 2010; Morais et al. 2011; Scholefield et al. 2015) and thus the response of these species when fed sustainable feeds with reduced levels of marine ingredients is unknown.

Studies have shown that dietary lipid content can have significant effects on gene expression in salmonids (Martinez-Rubio et al. 2013; Librán-Pérez et al. 2015; Hixson et al. 2017). Specifically, dietary lipid content 
affects the expression of key genes involved in the major lipid metabolic pathways in liver, as well the major transcription factors and nuclear receptors controlling and regulating the expression of these genes. This all impacts the lipid and fatty acid composition of liver (Martinez-Rubio et al. 2013). Furthermore, recent studies have shown that not only dietary lipid content but also LC-PUFA content can significantly affect the expression of a range of genes associated with lipid metabolism, as might be expected, and other pathways including antioxidant genes (Betancor et al. 2014a; Glencross et al. 2015). Thus, studying the metabolic impact of dietary lipid, including effects on lipid and fatty acid compositions, and the expression of genes of major lipid metabolic pathways is highly relevant in ABT. In addition, the high culture temperature conditions $\left(\sim 28{ }^{\circ} \mathrm{C}\right)$, strong aeration/oxygenation, and the high level of dietary pro-oxidants used for rearing ABT may promote highly pro-oxidative conditions. In consequence, it is of considerable relevance to evaluate the antioxidant protection status of juvenile ABT.

The overarching aim of the present study was to determine the impacts of dietary lipid content (15\% vs. $20 \%$; trial A) and dietary lipid source (100\% krill oil vs. $50 \%$ krill oil $/ 50 \%$ rapeseed oil; trial B) on fish performance, feed utilization, and expression of genes of lipid metabolism and regulation in liver, and the antioxidant system in ABT juveniles recently weaned from live feeds to inert formulated feed. In order to do so, extruded experimental feeds based on dried fish hydrolysate, fishmeal, and squid meal as protein source plus krill oil and rapeseed oil as lipid sources were formulated, produced, and fed to weaned juvenile ABT (41 days after hatch, dah).

\section{Materials and methods}

\section{Experimental fish}

ABT juveniles were produced from two different batches of eggs spawned in summer 2017 from captive wild broodstock fish maintained in floating net cages located at El Gorguel, off the Cartagena coast, SE Spain. The collected eggs were transferred to the Planta Experimental de Cultivos Marinos, Instituto Español de Oceanografía (IEO), Puerto de Mazarrón (Murcia), Spain for hatching and initial larviculture (Ortega 2015; De la Gándara et al. 2016). Fish were weaned from the live feed stage, fed gilthead sea bream (Sparus aurata L.) yolk sac larvae as prey, to formulated feed at 27 dah, using a commercial diet (Magokoro®; MGK; Marubeni Nisshin Feed Co., Japan), which had been successfully used as a formulated feed for PBT (Okada et al. 2014; Kurata et al. 2015; Honryo et al. 2018). The ABT were weaned using MGK at 0.6 to $0.9 \mathrm{~mm}$ pellet sizes and were completely weaned by $32 \mathrm{dah}$.

Experimental diets

The nutritional trials consisted of two consecutive 10day feeding trials (A and B) with weaned 41 dah ABT juveniles, from two different batches of spawned ABT eggs. Each trial investigated two experimental extruded feeds in comparison to the commercial reference feed (MGK), which was used in the present trials to benchmark the experimental feeds. Trial A tested dietary lipid level and used two experimental feeds formulated with krill oil (KO) to supply lipid at $15 \%$ and $20 \%$ on a dry mass basis (15KO and 20KO, respectively) in comparison to the commercial MGK reference feed, which was formulated with fish oil (FO). Trial B examined the effects of replacing $50 \%$ of $\mathrm{KO}$ with rapeseed oil (RO), to determine the impact of different dietary fatty acid composition, using two experimental feeds formulated to supply $15 \%$ lipid, one with $100 \% \mathrm{KO}(15 \mathrm{KO})$, the other with $50 \% \mathrm{KO}$ and $50 \% \mathrm{RO}$ (15KORO), in comparison to the MGK reference. The three experimental diets $(15 \mathrm{KO}, 20 \mathrm{KO}$, and $15 \mathrm{KORO})$ were formulated and produced by extrusion (Sparos Lda., Olhão, Portugal). The formulations and analyzed proximate compositions of the reference and test diets are shown in Tables 1 and 2. Crude protein was approximately $56 \%$ on a dry-matter basis and crude lipid content was $17.9 \%$ in the reference diet, $14.3 \%$ and $14.7 \%$ in the test diets $15 \mathrm{KO}$ and $15 \mathrm{KORO}$, respectively, while diet 20KO contained $18.9 \%$ total lipid. Diets $15 \mathrm{KO}$ and 15KORO were isocaloric $\left(20.2 \mathrm{~kJ} \mathrm{~g}^{-1}\right)$ whereas diet 20KO had higher energy level $\left(21.3 \mathrm{~kJ} \mathrm{~g}^{-1}\right)$.

Total lipid fatty acid composition, expressed as percent total fatty acid or micrograms per milligram dry mass, of the reference and experimental diets are presented in Table 3. Diets based on krill oil alone (15KO and 20KO) showed the highest values for total $n-3$ PUFA ( $41.5 \%$ and $43.2 \%$, respectively), with levels of $22: 6 n-3$ (DHA) $22 \%$ and $22.6 \%$, respectively, and 20:5n-3 (EPA) $13.3 \%$ and $14.2 \%$, respectively. Lowest values for these fatty acids were found in diet $15 \mathrm{KORO}$, 
Table 1 Formulation of the experimental feeds

\begin{tabular}{llll}
\hline & $15 \mathrm{KO}^{\mathrm{a}}$ & $20 \mathrm{KO}^{\mathrm{b}}$ & $15 \mathrm{KORO}^{\mathrm{c}}$ \\
\hline Ingredients (\%) & & & \\
Micronized fish meal $^{1}$ & 12.0 & 12.6 & 12.5 \\
Squid meal $^{2}$ & 15.0 & 15.7 & 15.0 \\
${\text { CPSP } 90^{3}}^{3}$ & 30.0 & 30.0 & 30.0 \\
Krill oil $^{4}$ & 9.4 & 13.9 & 4.7 \\
Rapeseed oil $^{5}$ & - & - & 4.7 \\
${\text { Algatrium DHA } 70^{6}}^{6}$ & 2.5 & 3.5 & 2.0 \\
Starch $^{7}$ & 9.8 & 3.0 & 9.8 \\
Vitamin and mineral premix $^{8}$ & 2.00 & 2.00 & 2.00 \\
${\text { Lutavit C } 35^{9}}^{\text {NaH }}{ }_{2} \mathrm{PO}_{4}{ }^{10}$ & 0.10 & 0.10 & 0.10 \\
Taurine $^{11}$ & 4.50 & 4.50 & 4.50 \\
Attractant AA mix $^{12}$ & 2.00 & 2.00 & 2.00 \\
Technical additives $^{13}$ & 0.50 & 0.50 & 0.50 \\
Organic Se $^{14}$ & 2.70 & 2.70 & 2.70 \\
Binders $^{15}$ & 0.50 & 0.50 & 0.50 \\
\hline & 9.00 & 9.00 & 9.00 \\
\hline
\end{tabular}

a $15 \mathrm{KO}, 15 \%$ total lipid as krill oil

b $20 \mathrm{KO}, 20 \%$ total lipid as krill oil

${ }^{\mathrm{c}} 15 \mathrm{KORO}, 15$ total lipid as $50 \%$ krill oil and 50\% European rapeseed oil

${ }^{1}$ Micronorse, Troms $\varnothing$ Fiskeindustri A/S, Tromsø, Norway

${ }^{2}$ Sopropêche, France

${ }^{3}$ CPSP 90, fresh fish by-products enzymatically hydrolyzed soluble fish protein concentrated (82-86\% protein), Sopropêche, France

${ }^{4}$ Qrill Aqua phospholipid oil, Aker Biomarine, Norway

${ }^{5}$ Euroingredientes, Cacém, Portugal

${ }^{6}$ Neoquimica, Carregado, Portugal

${ }^{7}$ Formulab, Maia, Portugal

${ }^{8}$ Vitamin and mineral premix. Vitamins (IU or $\mathrm{mg} \mathrm{kg}^{-1}$ diet): sodium menadione bisulfate, $40 \mathrm{mg}$; retinyl acetate, 32,000 IU; DL-cholecalciferol, $6800 \mathrm{IU}$; thiamin, $32 \mathrm{mg}$; riboflavin, $80 \mathrm{mg}$; pyridoxine, $40 \mathrm{mg}$; cyanocobalamin, $0.08 \mathrm{mg}$; nicotinic acid, $280 \mathrm{mg}$; folic acid, $24 \mathrm{mg}$; inositol, $1200 \mathrm{mg}$; biotin, $2.8 \mathrm{mg}$; calcium panthotenate, $120 \mathrm{mg}$; betaine, $1600 \mathrm{mg}$. Minerals ( $\mathrm{g}$ or $\mathrm{mg} / \mathrm{kg}$ diet): cobalt carbonate, $1.3 \mathrm{mg}$; copper sulfate, $18 \mathrm{mg}$; ferric sulfate, $12 \mathrm{mg}$; potassium iodide, $1.0 \mathrm{mg}$; manganese oxide, $19.2 \mathrm{mg}$; sodium selenite, $0.02 \mathrm{mg}$; zinc sulfate, $15 \mathrm{mg}$; excipient wheat middlings

${ }^{9}$ Ascorbil monophosphate, PREMIX Lda, Portugal

${ }^{10}$ Monosodium phosphate, Fosfitalia, Italy

${ }^{11}$ L-Taurine 98.5\%: Ajinomoto Eurolysine SAS, France

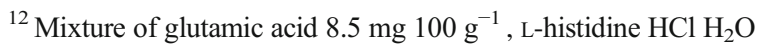
$232.8 \mathrm{mg} 100 \mathrm{~g}^{-1}$, and inosine-5/-monophosphate $2 \mathrm{Na}$

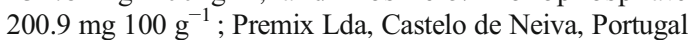

${ }^{13}$ Proprietary product, Sparos Lda., Olhão, Portugal

${ }^{14}$ Premix Lda, Castelo de Neiva, Portugal

${ }^{15}$ Proprietary binder mix, Sparos Lda., Olhão, Portugal
Table 2 Analyzed proximate composition (\% of dry mass), gross energy $\left(\mathrm{kJ} \mathrm{g}^{-1}\right), \alpha$-tocopherol, ascorbic acid $\left(\mathrm{mg} \mathrm{kg}^{-1}\right)$, taurine $\left(\mathrm{mg} \mathrm{g}^{-1}\right)$, and mineral (macroelements as $\mathrm{mg} \mathrm{g}^{-1}$ and microelements as $\mu \mathrm{g} \mathrm{g}^{-1}$ ) contents of the reference and test diets

\begin{tabular}{|c|c|c|c|c|}
\hline & MGK & $15 \mathrm{KO}$ & $20 \mathrm{KO}$ & $15 \mathrm{KORO}$ \\
\hline Crude protein (\% DM) & 55.7 & 56.3 & 57.9 & 56.4 \\
\hline Crude lipid (\% DM) & 17.9 & 14.3 & 18.9 & 14.7 \\
\hline Protein/lipid & 3.1 & 3.9 & 3.1 & 3.8 \\
\hline Carbohydrate (\% DM) & 14.9 & 11.7 & 9.1 & 7.0 \\
\hline Ash (\% DM) & 7.2 & 10.4 & 10.7 & 10.1 \\
\hline Gross energy ( $\mathrm{kJ} \mathrm{g}^{-1}$ ) & 21.8 & 20.2 & 21.3 & 20.2 \\
\hline$\alpha$-Tocopherol (mg kg ${ }^{-1}$ ) & 1479.6 & 311.6 & 341.0 & 252.7 \\
\hline Ascorbic acid $\left(\mathrm{mg} \mathrm{kg}^{-1}\right)$ & 1852.7 & 908.2 & 918.6 & 868.1 \\
\hline Taurine $\left(\mathrm{mg} \mathrm{g}^{-1}\right)$ & 6.1 & 28.1 & 23.8 & 26.4 \\
\hline \multicolumn{5}{|l|}{ Macrominerals ( $\mathrm{mg} \mathrm{g}^{-1}$ ) } \\
\hline Sodium & 7.0 & 1.3 & 1.3 & 1.3 \\
\hline Magnesium & 1.6 & 3.0 & 3.4 & 3.3 \\
\hline Phosphorus & 12.8 & 18.7 & 19.7 & 9.6 \\
\hline Potassium & 10.4 & 6.5 & 6.6 & 6.6 \\
\hline Calcium & 9.5 & 9.8 & 10.1 & 10.1 \\
\hline \multicolumn{5}{|l|}{ Microminerals $\left(\mu \mathrm{g} \mathrm{g}^{-1}\right)$} \\
\hline Chromium & 1.0 & 18.8 & 29.9 & 24.9 \\
\hline Manganese & 66.2 & 25.8 & 29.7 & 41.1 \\
\hline Iron & 582.5 & 578.3 & 762.9 & 601.2 \\
\hline Cobalt & 0.7 & 0.9 & 1.2 & 1.2 \\
\hline Copper & 11.1 & 24.3 & 27.6 & 30.7 \\
\hline Zinc & 208.4 & 60.4 & 90.0 & 93.6 \\
\hline Selenium & 6.3 & 12.3 & 12.0 & 12.0 \\
\hline
\end{tabular}

Results are means of duplicate analyses

$M G K$ reference diet (Magokoro Nishin Marubeni®, Japan), $15 \mathrm{KO}$ $15 \%$ lipid as krill oil, $20 \mathrm{KO} 20 \%$ lipid as krill oil, $15 \mathrm{KORO} 15 \%$ lipid (1:1 krill oil and rapeseed oil)

although similar to those in the reference MGK diet. In absolute terms, the content of DHA ranged from $15.5 \mu \mathrm{g} \mathrm{mg}^{-1}$ diet dry mass in diet 15KORO up to $29.5 \mu \mathrm{g} \mathrm{mg}^{-1}$ diet dry mass in diet $20 \mathrm{KO}$ with the reference and $15 \mathrm{KO}$ diets showing intermediate levels of 20.4 and $22.6 \mu \mathrm{g}$ of DHA per milligram diet dry mass, respectively. Total saturated fatty acids, primarily 16:0, were about $28 \%$ of total fatty acids in all diets except diet $15 \mathrm{KORO}$ that showed only $20 \%$ while, in contrast, monoenes were highest in this diet ( $40 \%$ due to the high content of $18: 1 \mathrm{n}-9)$. The inclusion of $50 \%$ $\mathrm{RO}$ in diet $15 \mathrm{KORO}$ resulted in this diet presenting the highest values for $18: 2 n-6$ (LA) $(7.8 \%)$ and $18: 3 n-3$ (LNA) $(3.9 \%)$. 
Table 3 Total lipid fatty acid composition, expressed as $\%$ total fatty acid and $\mu \mathrm{g} \mathrm{mg}{ }^{-1}$ mass (in brackets), of the reference and experimental diets

\begin{tabular}{|c|c|c|c|c|}
\hline & MGK & $15 \mathrm{KO}$ & $20 \mathrm{KO}$ & $15 \mathrm{KORO}$ \\
\hline $14: 0$ & $5.3(6.6)$ & $6.8(6.9)$ & $7.0(9.2)$ & $3.6(3.6)$ \\
\hline $16: 0$ & $17.8(22.3)$ & $16.5(16.9)$ & $16.5(21.5)$ & $12.1(12.1)$ \\
\hline 18:0 & $4.7(5.9)$ & $4.3(4.4)$ & $3.4(4.4)$ & $4.2(4.1)$ \\
\hline Total SFA ${ }^{1}$ & $29.1(36.3)$ & $28.3(28.9)$ & $27.5(35.8)$ & $20.6(20.6)$ \\
\hline $16: 1 n-7$ & $4.9(6.2)$ & $4.9(5.0)$ & $5.0(6.5)$ & $3.0(3.0)$ \\
\hline $18: 1 n-9$ & $13.5(16.9)$ & $10.9(11.1)$ & $10.3(11.5)$ & $27.0(26.9)$ \\
\hline $18: 1 n-7$ & $3.3(4.1)$ & $4.6(4.7)$ & $4.9(6.3)$ & $3.9(3.9)$ \\
\hline $20: 1 n-9$ & $1.9(2.4)$ & $2.2(2.3)$ & $1.9(2.4)$ & $2.5(2.5)$ \\
\hline Total MUFA ${ }^{2}$ & $30.7(38.4)$ & $26.0(26.6)$ & $25.2(32.9)$ & $39.7(39.5)$ \\
\hline $18: 2 n-6$ & $5.6(7.0)$ & $2.2(2.2)$ & $2.0(2.6)$ & $7.8(7.8)$ \\
\hline $20: 4 n-6$ & $1.1(1.4)$ & $0.6(0.6)$ & $0.6(0.7)$ & $0.5(0.5)$ \\
\hline Total n-6 PUFA ${ }^{3}$ & $7.7(9.6)$ & $3.4(3.4)$ & $3.1(4.1)$ & $8.7(8.7)$ \\
\hline $18: 3 n-3$ & $1.2(1.5)$ & $0.9(1.0)$ & $0.9(1.2)$ & $3.9(3.9)$ \\
\hline $18: 4 n-3$ & $1.8(2.2)$ & $2.0(2.0)$ & $2.1(2.7)$ & $1.1(1.1)$ \\
\hline $20: 4 n-3$ & $0.7(0.9)$ & $0.4(0.4)$ & $0.4(0.5)$ & $0.3(0.3)$ \\
\hline $20: 5 n-3$ & $8.9(11.1)$ & $13.3(13.6)$ & $14.2(18.5)$ & $7.7(7.7)$ \\
\hline $22: 5 n-3$ & $2.4(3.0)$ & $2.7(2.8)$ & $2.8(3.7)$ & $2.0(2.0)$ \\
\hline $22: 6 n-3$ & $16.3(20.4)$ & $22.0(22.6)$ & $22.6(29.5)$ & $15.5(15.5)$ \\
\hline Total n-3 PUFA ${ }^{4}$ & $31.5(39.3)$ & $41.5(42.5)$ & $43.2(56.4)$ & $30.5(30.5)$ \\
\hline Total PUFA & $40.2(50.2)$ & $45.8(46.9)$ & $47.3(61.7)$ & 39.7 (39.7) \\
\hline$n-3 / n-6$ & 4.1 & 12.2 & 13.9 & 3.5 \\
\hline DHA/EPA & 1.8 & 1.6 & 1.6 & 2.0 \\
\hline
\end{tabular}

Results are means of duplicate analyses. ${ }^{1}$ Totals include 15:0, 20:0, 22:0, and 24:0. ${ }^{2}$ Totals include 16:1n-9, 18:1n-11, 20:1n-7, 22:1 isomers, and $24: 1{ }^{3}$ Totals include 18:3n-6, 20:2n-6,22:4n-6, and 22:5n-6. ${ }^{4}$ Totals include 20:3n-3 and 22:3n-3

DHA docosahexaenoic acid, EPA eicosapentaenoic acid, $M G K$ reference diet (Magokoro Nishin Marubeni®, Japan), MUFA monounsaturated fatty acid, PUFA, polyunsaturated fatty acid, SFA saturated fatty acid, $15 \mathrm{KO} 15 \%$ total lipid as krill oil, $20 \mathrm{KO} 20 \%$ total lipid as krill oil, 15 KORO $15 \%$ total lipid (1:1 krill oil and rapeseed oil)

\section{Experimental protocol}

Prior to initiation of the feeding trials, from 32 to 41 dah, ABT juveniles were fed with a 1:1:1 mixture of MGK, $15 \mathrm{KO}$, and $20 \mathrm{KO}$ for trial $\mathrm{A}$, and MGK, $15 \mathrm{KO}$, and $15 \mathrm{KORO}$ for trial $\mathrm{B}$. Both trials were carried out in duplicate tanks per treatment, with each tank containing either 40 or 46 ABT juveniles in trials A and B, respectively, with fish fed one of the dietary treatments, pellet size $1.2 \mathrm{~mm}$, from 41 to 51 dah when trials were terminated and fish sampled. Thus, six cylindroconical $5-\mathrm{m}^{3}$ tanks were used in an open flow system with incoming seawater filtered at $10 \mu \mathrm{m}$ and UV sterilized. Rearing conditions during the experimental period are shown in Supplementary Table 1. Fish were hand-fed to satiation every $2 \mathrm{~h}$, during the light hours of the photoperiod, eight times per day. The feeding trials and all experimental (sampling) procedures were carried out according to Spanish (RD 53/2013; BOE 8th February 2013) and EU legislation (Directive 2010/63/EU) on the protection of animals used for scientific purposes. The trials were also subject to ethical review by the Animal Welfare and Ethical Review Board of the University of Stirling. In this respect, it is important to note that the trials were run for the minimum duration (10 days) required to produce a 2- to 3-fold increase in weight, which is the generally accepted standard for fish nutritional trials. This was because the major cause of death in ABT juveniles in tanks at this stage is collision with the tank walls (Miyashita et al. 2000), and so the trial duration was limited by considerations of fish welfare. However, similarly short trials testing dietary oil sources 
have been successfully performed with juvenile PBT (Agawa et al. 2012).

Sampling for biometrical, biochemical, and molecular analysis

At the initiation of the feeding trials (41 dah), 30 randomly caught ABT juveniles were euthanized by a lethal dose of anesthetic ( $0.02 \%$ 2-phenoxyethanol; Sigma, Spain), weights and total lengths recorded, and individual fish photographed while measuring. At the end of the trials (51 dah), surviving ABT juveniles from all treatment replicates were measured and weighed with final survival (\%) calculated by counting juveniles at the beginning and end of the trial from every replicate tank. Growth performance and feed utilization response variables including mean weight $(\mathrm{g})$, mean length $(\mathrm{cm})$, percent weight gain (\%), specific growth rate (SGR) as percentage of daily growth increase, feed conversion ratio (FCR), condition factor (CF), and daily feeding rate (DFR, \%) were calculated using the following formulae.

Weight gain $(\%)=$ (average weight gain/ average initial body weight $\times 100$, where average SGR $\left(\%\right.$ day $\left.^{-1}\right)=\left[\left(\ln W_{2}-\ln W_{1}\right) /\right.$ time $($ days $\left.)\right] \times 100$, where $W_{1}$ and $W_{2}$ denote the initial and final weight (g), respectively.FCR $=$ dry feed intake $(\mathrm{g}) /$ wet weight gain $(\mathrm{g}) \cdot \mathrm{CF}=\left(W / L^{3}\right) \times 100$, where $W$ and $L$ denote wet body weight $(\mathrm{g})$ and fork length $(\mathrm{cm})$, respectively.DFR $(\%)=$ feed intake (dry matter) $/ 100$ $/[$ (initial fish weight + final fish weight $) 10$ days fed/ 2].

At the end of the feeding trials and after total weight and length were measured, livers and/or small pieces of muscular tissue of three individual ABT juveniles per tank were dissected and preserved for biochemical and molecular analyses. For molecular analyses, approximately $100-150 \mathrm{mg}$ of liver tissue (samples of individual livers from three fish per tank; six per dietary treatment) were placed in $1 \mathrm{ml} \mathrm{RNAlater}{ }^{\circledR}$ (Sigma-Aldrich, Dorset, UK) and processed according to the manufacturer's instructions $\left(4^{\circ} \mathrm{C}\right.$ for $\left.24 \mathrm{~h}\right)$ before storage at $80{ }^{\circ} \mathrm{C}$ for RNA extraction and subsequent molecular analysis. Duplicate samples of livers and muscle per tank (pooled samples of liver/muscle from three fish per tank, two per dietary treatment) were immediately frozen in liquid $\mathrm{N}_{2}$ and stored at $-80{ }^{\circ} \mathrm{C}$ prior to biochemical analysis.
Biochemical analysis

\section{Proximate composition of diets}

Gross proximate compositions of feeds (protein, lipid, ash, and moisture) were determined according to standard procedures (AOAC 2000). Moisture contents were obtained after drying in an oven at $110{ }^{\circ} \mathrm{C}$ for $24 \mathrm{~h}$ and ash content determined after incineration at $600{ }^{\circ} \mathrm{C}$ for $16 \mathrm{~h}$. Crude protein was measured by determining nitrogen content $(\mathrm{N} \times 6.25)$ using automated Kjeldahl analysis (Tecator Kjeltec Auto 1030 analyzer; Foss, Warrington, UK) and crude lipid content determined gravimetrically after Soxhlet lipid extraction (Tecator Soxtec system 2050 Auto Extraction apparatus).

\section{Total lipid extraction and quantification and fatty acid analysis}

Total lipid was extracted from feeds, pooled livers, and muscular tissue (livers/muscle of three fish per tank pooled) of ABT juveniles fed the different dietary regimes according to the method of Folch et al. (1957). Approximately $200 \mathrm{mg}$ of ground feed or hepatic tissue was placed in ice-cold chloroform/methanol (2:1, by vol) and homogenized with an Ultra-Turrax tissue disrupter (Fisher Scientific, Loughborough, UK). The nonlipid and lipid layers were separated by addition of $0.88 \%(w / v) \mathrm{KCl}$ and allowed to separate on ice for $1 \mathrm{~h}$. The upper aqueous layer was aspirated and the lower organic layer dried under oxygen-free nitrogen. The lipid content was determined gravimetrically after drying overnight in a vacuum desiccator.

Fatty acid methyl esters (FAMEs) of total lipid were prepared by acid-catalyzed trans-esterification at $50{ }^{\circ} \mathrm{C}$ for $16 \mathrm{~h}$ according to the method of Christie (2003). The FAMEs were separated and quantified by gas-liquid chromatography (Agilent Technologies 7890B GC System) using a $30 \mathrm{~m} \times 0.32 \mathrm{~mm}$ i.d. fused silica capillary column (SUPELCOWAX ${ }^{\mathrm{TM}}-10$; Supelco Inc., Bellefonte, USA) and on-column injection at $50{ }^{\circ} \mathrm{C}$. Hydrogen was used as carrier gas and temperature programming was from 50 to $150^{\circ} \mathrm{C}$ at $40{ }^{\circ} \mathrm{C} / \mathrm{min}$ and then to $230{ }^{\circ} \mathrm{C}$ at $2.0^{\circ} \mathrm{C} / \mathrm{min}$. Individual methyl esters were identified by comparison with known standards and by reference to published data (Ackman 1980; Tocher and Harvie 1988). Data were collected and processed using Agilent Technologies Openlab CDS Chemstation for Windows (version A.02.05.21). 
Determination of alpha-tocopherol (vitamin E), ascorbic acid (vitamin C), and taurine contents in reference and test diets

Alpha-tocopherol concentrations in reference and test diets were determined using high-pressure liquid chromatography (HPLC) with UV detection. Samples were weighed, homogenized in pyrogallol, and saponified essentially as described by McMurray et al. (1980) according to Cowey et al. (1981). HPLC analysis was performed using a $150 \times 4.6 \mathrm{~mm}$, reverse-phase Luna $5 \mu \mathrm{m} \mathrm{C} 18$ column (Phenomenex, CA, USA). The mobile phase was $98 \%$ methanol pumped at $1.0 \mathrm{ml} \mathrm{min}^{-1}$. The effluent from the column was monitored at a wavelength of $293 \mathrm{~nm}$ and quantification achieved by comparison with alpha-tocopherol (Sigma-Aldrich) as external standard.

The concentration of vitamin $\mathrm{C}$ was determined as described by Betancor et al. (2012a). Samples were weighed, homogenized, and dissolved in $0.4 \mathrm{M}$ phosphate buffer (adjusted to $\mathrm{pH} 3.0$ with phosphoric acid). The samples were centrifuged at $1500 \mathrm{xg}$, supernatants removed and filtered through a disposable $0.45-\mu \mathrm{m}$ filter and stored at $4{ }^{\circ} \mathrm{C}$ until the measurement in a HPLC with UV detection. The determination of vitamin $\mathrm{C}$ concentration was achieved by comparison with tris (cyclohexylammonium) ascorbic acid-2-phosphate (Sigma-Aldrich) as the external standard.

Taurine in feeds was analyzed by reverse-phase HPLC using a Nova Pak C18 column $(3.9 \times 300 \mathrm{~mm})$ (Waters Corporation, MA, USA) fitted with a Nova Pack C18 precolumn $(3.9 \times 20 \mathrm{~mm})$ according to the method of Bidlingmeyer et al. (1987). Separation was achieved over $65 \mathrm{~min}$ at $52{ }^{\circ} \mathrm{C}$ with a flow rate of $1 \mathrm{ml} \mathrm{min}{ }^{-1}$, using a gradient between two solvents: $70 \mathrm{mM}$ sodium acetate at $\mathrm{pH} 6.55$ with $2.5 \%$ of acetonitrile (solvent A) and water-acetonitrile-methanol, 40:45:15 v/v (solvent B) with UV detection at $254 \mathrm{~nm}$.

\section{Mineral analysis}

Total selenium and other minerals in feeds were measured according to the methods described in Betancor et al. (2012b) using inductively coupled plasma mass spectrometry (ICP-MS) with collision cell technology (Thermo X Series 2; Thermo Scientific, Hemel-Hempstead, UK) using argon and hydrogen as carrier gases. Briefly, between 50 and $100 \mathrm{mg}$ of ground feed sample was added to Teflon tubes and digested in a microwave digester (MARS Xpress; CEM Microwave Technology Ltd., Buckingham, UK) with $5 \mathrm{ml}$ of $69 \%$ nitric acid in three stages: $21-190{ }^{\circ} \mathrm{C}$ for $10 \mathrm{~min}$ at $800 \mathrm{~W}$ followed by $190{ }^{\circ} \mathrm{C}$ for $20 \mathrm{~min}$ at $800 \mathrm{~W}$ followed by a final 30 -min cooling period. The digested solution was made up to a $10-\mathrm{ml}$ volume with deionized water and total minerals determined by adding $0.4 \mathrm{ml}$ of this solution to $10-\mathrm{ml}$ tubes and adjusting volume $(10 \mathrm{ml})$ using deionized water before analyzing by ICP-MS. For total selenium, $10 \mu \mathrm{l}$ of internal standard (aqueous solution of gallium and scandium, $10 \mathrm{ppm}$; BDH Chemicals Ltd., Poole, UK) and $0.2 \mathrm{ml}$ methanol were added to $0.4 \mathrm{ml}$ of the initial digest before adjusting the volume to $10 \mathrm{ml}$ with deionized water prior to analysis by ICP-MS.

Tissue RNA extraction and cDNA synthesis

Samples were homogenized in $1 \mathrm{ml}$ of TriReagent ${ }^{\circledR}$ (Sigma-Aldrich) RNA extraction buffer using a bead tissue disruptor (Bio Spec, Bartlesville, Oklahoma, USA). Total RNA was isolated following manufacturer's instructions and quantity and quality determined by spectrophotometry using a Nanodrop ND-1000 (Labtech Int., East Sussex, UK), and electrophoresis using $200 \mathrm{ng}$ of total RNA in a 1\% agarose gel. cDNA was synthesized using $2 \mu \mathrm{g}$ of total RNA and random primers in $20-\mu \mathrm{l}$ reactions and the high-capacity reverse transcription kit without RNase inhibitor according to the manufacturer's protocol (Applied Biosystems, Warrington, UK).

Quantitative RT-polymerase chain reaction analysis

Transcript abundance was determined by quantitative RT-polymerase chain reaction (qPCR) of candidate genes involved in key pathways related to lipid and fatty acid metabolism, and antioxidant system enzymes. Specifically, qPCR was carried out on transcription factors pparo, ppar $\gamma$, lxr, rxr, srebp1, and srebp2; LC-PUFA biosynthesis genes fads $2 d 6$ and elovl5; fatty acid metabolism genes fas, cpt1, aco, fabp2, fabp4, fabp7, lpl, and $\mathrm{hmgcl}$; and the antioxidant enzymes sod, cat, gpxl, and gpx4. Elongation factor-1 $\alpha($ elf1 $\alpha)$ and $\beta$-actin (bactin) were used as reference genes. The cDNA was diluted 20-fold with Milli-Q water. The efficiency of the primers for each gene was previously evaluated by serial dilutions of cDNA pooled from the samples to guarantee it was $>85 \%$ for all primer pairs. qPCR was performed 
using a Biometra TOptical Thermocycler (Analytik Jena, Goettingen, Germany) in 96-well plates in duplicate $20 \mu \mathrm{l}$ reaction volumes containing $10 \mu \mathrm{l}$ of Luminaris Color HiGreen qPCR Master Mix (Thermo Scientific, Hemel Hempstead, UK), $1 \mu$ of the primer corresponding to the analyzed gene $(10 \mathrm{pmol}), 3 \mu \mathrm{l}$ of molecular biology grade water, and $5 \mu$ of cDNA (1/20 diluted). In addition, amplifications were carried out with a systematic negative control (NTC, no template control) containing no cDNA. Standard amplification parameters included an UDG pre-treatment at $50{ }^{\circ} \mathrm{C}$ for $2 \mathrm{~min}$, an initial denaturation step at $95^{\circ} \mathrm{C}$ for $10 \mathrm{~min}$, followed by 35 cycles: $15 \mathrm{~s}$ at $95^{\circ} \mathrm{C}, 30 \mathrm{~s}$ at the annealing $T_{\mathrm{m}}$, and $30 \mathrm{~s}$ at $72{ }^{\circ} \mathrm{C}$. Primer sequences for genes are given in Table S2 (Supplementary material).

Statistical analysis

Results for biometry, growth, and feed utilization response variables and fatty acid compositions are presented as means \pm SD with $n=2$ for biochemical analyses or, with the accepted compromise of pseudoreplication, $n=6$ for gene expression. The data were checked for homogeneity of the variances by the Bartlett test and, where necessary, arc-sin transformed before further statistical analysis. Differences between mean values were analyzed by $t$ test and one-way analysis of variance (ANOVA) followed, when pertinent, by a multiple comparison test (Tukey). Differences rejecting the null hypothesis were reported as statistically significant when $P<0.05$ (Zar 1999). Gene expression results were analyzed using the relative expression software tool (REST 2009), which employs a pairwise fixed reallocation randomization test $(10,000$ randomizations) with efficiency correction (Pfaffl et al. 2002) to determine the statistical significance of expression ratios (gene expression fold changes) among treatments.

\section{Results}

ABT juvenile biometry, growth performance, feed utilization response, and survival

Growth performance, feed utilization, and survival of ABT juveniles fed the reference and experimental diets are shown in Table 4. In trial A, the greatest total length was shown for ABT juveniles fed MGK and $15 \mathrm{KO}$ diets with the lowest value for fish fed
20KO. Fish fed MGK also displayed the highest total wet weight, total weight gain, and SGR followed by fish fed $15 \mathrm{KO}$ and those fed $20 \mathrm{KO}$. Fish fed $15 \mathrm{KO}$ and MGK showed higher condition factor (CF). In contrast, feed utilization parameters such as feed conversion ratio (FCR), daily feeding rate (DFR), ingestion rate (IR), and survival did not show significant differences among treatments. In trial B, total wet weight and length were higher in fish fed diets $15 \mathrm{KO}$ and $15 \mathrm{KORO}$ and lower in those fed the MGK diet. The same pattern was shown for weight gain and SGR, while CF was higher in fish fed MGK and $15 \mathrm{KO}$, and lower in those fed the $15 \mathrm{KORO}$ diet. As in trial $\mathrm{A}$, in trial $\mathrm{B}$ feed utilization parameters and survival did not present significant differences among fish fed any of the diets (Table 4). Mortality was relatively high, as expected for ABT of this size in cylindroconical $5-\mathrm{m}^{3}$ tanks, and almost exclusively due to collisions with the tank wall and not related to feed (Miyashita et al. 2000).

Lipid contents and fatty acid compositions of total lipid of liver and muscle from ABT juveniles

In trial A, lipid content ( $\%$ of wet mass) of liver was highest in fish fed MGK (6.5\%), followed by those fed the $15 \mathrm{KO}$ diet $(3.4 \%)$ and lowest in liver of fish fed the $20 \mathrm{KO}$ diet (2.2\%) (Table 5). The proportion of total $n-3$ PUFA was highest in livers of fish fed the $15 \mathrm{KO}$ and 20KO diets, mainly due to high proportions of DHA with the highest in liver from fish fed $20 \mathrm{KO}$ followed by $15 \mathrm{KO}$, and lowest in fish fed diet MGK. Total n-6 PUFA content was highest in livers of fish fed MGK, mainly due to the high levels of $18: 2 n-6$ (LA) in this diet, followed by livers of fish fed the 20KO diet, which also showed the highest level of 20:4n-6 (ARA), followed by livers of fish fed $15 \mathrm{KO}$. The percentage of total saturated fatty acids, primarily 16:0, in liver total lipid was highest in fish fed diet $20 \mathrm{KO}$ followed by fish fed $15 \mathrm{KO}$ and MGK, whereas total monoenes were highest (30\%) in livers of fish fed the MGK diet, primarily due to levels of $18: 1 \mathrm{n}-9(15.7 \%)$, with levels in $15 \mathrm{KO}>20 \mathrm{KO}$.

In trial $\mathrm{B}$, lipid content of liver was highest in fish fed the reference MGK diet (10.0\%) followed by those fed $15 \mathrm{KORO}$ and $15 \mathrm{KO}$ diets at $3.7 \%$ and $5.4 \%$, respectively (Table 6). Total saturated fatty acids were highest in liver from fish fed the MGK and $15 \mathrm{KO}$ diets ( $27.2 \%$ and $29.4 \%$, respectively), primarily due to the levels of 16:0, and lowest in those of fish fed the 
Table 4 Growth performance, feed utilization, and survival of juvenile Atlantic bluefin tuna (Thunnus thynnus) fed reference and test diets

Trial A

Dietary treatments

Parameter measured

Initial wet weight $(\mathrm{g})$

MGK

Final wet weight (g)

$2.9 \pm 0.9$

$8.4 \pm 0.3^{\mathrm{a}}$

$6.5 \pm 0.7$

Initial fork length $(\mathrm{cm})$

$8.5 \pm 0.1^{\mathrm{a}}$

Weight gain (\%)

$188.4 \pm 16.3^{\mathrm{a}}$

Specific growth rate $\left(\right.$ SGR $\% \cdot$ day $^{-1}$ )

$19.4 \pm 0.4^{\mathrm{a}}$

Condition factor $\left(\mathrm{CF} \mathrm{g} / \mathrm{cm}^{3}\right)$

$1.3 \pm 0.1^{\mathrm{a}}$

Feed conversion ratio (FCR)

$0.8 \pm 0.0$

Daily feeding rate (DFR \%)

$6.5 \pm 0.5$

Survival (\%)

$25.0 \pm 10.6$

$\begin{array}{ll}15 \mathrm{KO} & 20 \mathrm{KO} \\ 2.9 \pm 0.9 & 2.9 \pm 0.9 \\ 8.0 \pm 0.2^{\mathrm{b}} & 6.0 \pm 0.3^{\mathrm{c}} \\ 6.5 \pm 0.7 & 6.5 \pm 0.7 \\ 8.5 \pm 0.1^{\mathrm{a}} & 8.1 \pm 0.1^{\mathrm{b}} \\ 177.1 \pm 13.6^{\mathrm{b}} & 107.5 \pm 8.8^{\mathrm{c}} \\ 19.0 \pm 0.2^{\mathrm{b}} & 15.5 \pm 0.5^{\mathrm{c}} \\ 1.3 \pm 0.1^{\mathrm{a}} & 1.1 \pm 0.1^{\mathrm{b}} \\ 1.0 \pm 0.0 & 0.9 \pm 0.1 \\ 7.3 \pm 0.7 & 8.4 \pm 0.5 \\ 35.6 \pm 11.5 & 15.0 \pm 0.1\end{array}$

Trial B

Dietary treatments

Parameter measured

Initial wet weight (g)

MGK

Final wet weight (g)

$3.3 \pm 0.6$

Initial fork length $(\mathrm{cm})$

$10.4 \pm 0.3^{\mathrm{b}}$

$6.7 \pm 0.4$

Final fork length $(\mathrm{cm})$

$9.1 \pm 0.1^{\mathrm{b}}$

Weight gain (\%)

Specific growth rate (SGR \% day $^{-1}$ )

$216.1 \pm 16.4^{\mathrm{b}}$

$22.1 \pm 0.2^{\mathrm{b}}$

Condition factor $\left(\mathrm{CF} \mathrm{g} / \mathrm{cm}^{3}\right)$

$1.4 \pm 0.1^{\mathrm{a}}$

Feed conversion ratio (FCR)

$1.0 \pm 0.0$

Daily feeding rate (DFR \%)

$6.0 \pm 0.5$

Survival (\%)

$23.8 \pm 6.1$

$15 \mathrm{KO}$

$15 \mathrm{KORO}$

$3.3 \pm 0.6$

$3.3 \pm 0.6$

$11.3 \pm 0.1^{\mathrm{a}}$

$11.2 \pm 0.1^{\mathrm{a}}$

$6.7 \pm 0.4$

$6.7 \pm 0.4$

$9.4 \pm 0.1^{\mathrm{a}}$

$9.4 \pm 0.1^{\mathrm{a}}$

$243.5 \pm 8.2^{\mathrm{a}}$

$242.2 \pm 19.6^{\mathrm{a}}$

$22.9 \pm 0.1^{\mathrm{a}}$

$23.0 \pm 0.2^{\mathrm{a}}$

$1.4 \pm 0.1^{\mathrm{a}}$

$1.3 \pm 0.1^{\mathrm{b}}$

$1.0 \pm 0.0$

$1.1 \pm 0.2$

$6.3 \pm 0.3$

$6.7 \pm 0.3$

$26.8 \pm 1.0$

$25.0 \pm 4.6$

Results are mean \pm SD ( $n=2$, with 20 animals measured per replicate). An SD of 0.0 implies an SD of $<0.05$. Values bearing different superscript letters are significantly different $(P<0.05)$

$M G K$ reference diet (Magokoro®, Marubeni Nisshin Feed Co., Japan), 15KO diet containing 15\% total lipid as krill oil, $20 K O$ diet containing $20 \%$ total lipid as krill oil, $15 \mathrm{KORO}$ diet containing $15 \%$ total lipid as $50 \%$ krill oil and $50 \%$ rapeseed oil

15KORO diet (Table 6). Total monoenes in liver total lipid were highest in fish fed the MGK and $15 \mathrm{KORO}$ diets $(30.8 \%$ and $33.4 \%$, respectively), due to the levels of $18: 1 \mathrm{n}-9$, which was highest in liver of fish fed diet 15KORO (23.7\%), followed by liver of fish fed the MGK diet (16.1\%) and lowest in fish fed diet $15 \mathrm{KO}(10.5 \%)$. Liver of fish fed the MGK and $15 \mathrm{KORO}$ diets showed the highest values of total $\mathrm{n}$ -6 PUFA ( $11.6 \%$ and $11.0 \%$, respectively) mainly due to high levels of LA ( $7.4 \%$ and $7.5 \%$, respectively), reflecting the inclusion of rapeseed oil, with lowest level in fish fed the $15 \mathrm{KO}$ diet. Highest ARA levels were observed in total lipid of livers from fish fed the reference MGK diet, followed by those fed the $15 \mathrm{KORO}$ and $15 \mathrm{KO}$ diets. The proportion of total $\mathrm{n}$ -3 PUFA was highest in liver of fish fed the $15 \mathrm{KO}$ diet
(37.6\%) followed by those fed MGK and 15KORO diets at $26.9 \%$ and $25.5 \%$, respectively. This was mainly due to the contribution of DHA with proportions of $23.5 \%, 15.4 \%$, and $13.7 \%$ for fish fed the $15 \mathrm{KO}, 15 \mathrm{KORO}$, and MGK diets, respectively, reflecting to a great extent dietary fatty acid compositions. The DHA/EPA ratio in liver lipid was, in decreasing order, 2.9 (15KORO), $2.6(15 \mathrm{KO})$, and 2.1 (MGK).

No differences were observed in muscle lipid content among fish fed the different diets in either trial A or trial B (Tables 5 and 6). In trial A, fish fed $15 \mathrm{KO}$ and $20 \mathrm{KO}$ had the highest DHA and total $\mathrm{n}-3$ LC-PUFA contents, while no differences were found in muscle total PUFA levels and, similarly, no differences were found in total saturated fatty acids 
Table 5 Lipid contents (\% of wet weight) and fatty acid compositions (\% of total fatty acids) of liver and muscle from juvenile Atlantic bluefin tuna (Thunnus thynnus L.) fed either a reference diet (Magokoro®), $15 \%$ lipid diet based on krill oil (15KO), or $20 \%$ lipid diet based on krill oil (20KO) in trial A

\begin{tabular}{|c|c|c|c|c|c|c|}
\hline & \multicolumn{3}{|l|}{ Liver } & \multicolumn{3}{|l|}{ Muscle } \\
\hline & MGK & $15 \mathrm{KO}$ & $20 \mathrm{KO}$ & MGK & $15 \mathrm{KO}$ & $20 \mathrm{KO}$ \\
\hline Total lipid (\%) & $6.5 \pm 0.8^{\mathrm{a}}$ & $3.4 \pm 0.7^{\mathrm{b}}$ & $2.2 \pm 0.1^{\mathrm{c}}$ & $0.8 \pm 0.2$ & $0.8 \pm 0.1$ & $0.8 \pm 0.0$ \\
\hline $14: 0$ & $2.5 \pm 0.1^{\mathrm{a}}$ & $1.6 \pm 0.3^{\mathrm{b}}$ & $0.5 \pm 0.1^{\mathrm{c}}$ & $0.8 \pm 0.1^{\mathrm{a}}$ & $0.7 \pm 0.1^{\mathrm{a}}$ & $0.3 \pm 0.0^{\mathrm{b}}$ \\
\hline $16: 0$ & $18.0 \pm 0.7^{\mathrm{c}}$ & $20.6 \pm 0.2^{\mathrm{b}}$ & $24.7 \pm 1.0^{\mathrm{a}}$ & $19.6 \pm 0.2^{\mathrm{a}}$ & $20.5 \pm 1.9^{\mathrm{a}}$ & $17.3 \pm 0.8^{\mathrm{b}}$ \\
\hline $18: 0$ & $6.3 \pm 0.2^{\mathrm{b}}$ & $6.8 \pm 0.1^{\mathrm{b}}$ & $11.4 \pm 0.5^{\mathrm{a}}$ & $10.9 \pm 0.3^{\mathrm{b}}$ & $10.5 \pm 0.4^{\mathrm{b}}$ & $14.1 \pm 0.4^{\mathrm{a}}$ \\
\hline Total SFA ${ }^{1}$ & $28.2 \pm 1.1^{\mathrm{b}}$ & $30.1 \pm 0.2^{\mathrm{b}}$ & $38.8 \pm 1.0^{\mathrm{a}}$ & $33.1 \pm 1.1$ & $33.6 \pm 1.9$ & $34.3 \pm 0.7$ \\
\hline $16: 1 n-7$ & $3.7 \pm 0.2^{\mathrm{a}}$ & $2.6 \pm 0.2^{\mathrm{b}}$ & $1.1 \pm 0.1^{\mathrm{c}}$ & $1.3 \pm 0.2^{\mathrm{a}}$ & $1.2 \pm 0.2^{\mathrm{a}}$ & $0.7 \pm 0.1^{\mathrm{b}}$ \\
\hline $18: 1 n-9$ & $15.6 \pm 0.7^{\mathrm{a}}$ & $9.6 \pm 0.3^{\mathrm{b}}$ & $5.8 \pm 1.3^{\mathrm{c}}$ & $9.0 \pm 0.4^{\mathrm{a}}$ & $8.0 \pm 0.1^{\mathrm{b}}$ & $7.8 \pm 0.6^{\mathrm{b}}$ \\
\hline $18: 1 n-7$ & $4.1 \pm 0.2^{\mathrm{a}}$ & $4.5 \pm 0.1^{\mathrm{a}}$ & $3.0 \pm 0.3^{\mathrm{b}}$ & $3.0 \pm 0.2^{\mathrm{b}}$ & $3.8 \pm 0.1^{\mathrm{a}}$ & $3.7 \pm 0.1^{\mathrm{a}}$ \\
\hline $20: 1 n-9$ & $2.0 \pm 0.1^{\mathrm{a}}$ & $1.2 \pm 0.1^{\mathrm{b}}$ & $0.3 \pm 0.0^{\mathrm{c}}$ & $0.7 \pm 0.1^{\mathrm{a}}$ & $0.9 \pm 0.1^{\mathrm{a}}$ & $0.5 \pm 0.0^{\mathrm{b}}$ \\
\hline Total MUFA ${ }^{2}$ & $30.0 \pm 1.2^{\mathrm{a}}$ & $19.8 \pm 0.3^{\mathrm{b}}$ & $12.1 \pm 2.2^{\mathrm{c}}$ & $17.8 \pm 0.4^{\mathrm{a}}$ & $15.0 \pm 0.1^{\mathrm{b}}$ & $13.7 \pm 0.4^{\mathrm{b}}$ \\
\hline $18: 2 n-6$ & $6.9 \pm 0.3^{\mathrm{a}}$ & $1.8 \pm 0.2^{\mathrm{b}}$ & $0.9 \pm 0.1^{\mathrm{c}}$ & $3.3 \pm 0.1^{\mathrm{a}}$ & $1.4 \pm 0.1^{\mathrm{b}}$ & $1.3 \pm 0.1^{\mathrm{b}}$ \\
\hline $20: 4 n-6$ & $1.7 \pm 0.1^{\mathrm{b}}$ & $1.3 \pm 0.1^{\mathrm{c}}$ & $2.4 \pm 0.1^{\mathrm{a}}$ & $2.0 \pm 0.1^{\mathrm{a}}$ & $1.2 \pm 0.1^{\mathrm{c}}$ & $1.6 \pm 0.1^{\mathrm{b}}$ \\
\hline $22: 5 n-6$ & $0.7 \pm 0.1$ & $0.9 \pm 0.1$ & $1.1 \pm 0.1$ & $1.6 \pm 0.1^{\mathrm{a}}$ & $1.0 \pm 0.1^{\mathrm{b}}$ & $1.2 \pm 0.2^{\mathrm{b}}$ \\
\hline Total n-6 PUFA ${ }^{3}$ & $11.3 \pm 0.4^{\mathrm{a}}$ & $5.7 \pm 0.3^{\mathrm{c}}$ & $6.8 \pm 0.6^{\mathrm{b}}$ & $8.2 \pm 0.1^{\mathrm{a}}$ & $5.6 \pm 0.3^{\mathrm{c}}$ & $6.6 \pm 0.1^{b}$ \\
\hline $18: 3 n-3$ & $0.8 \pm 0.1^{\mathrm{a}}$ & $0.5 \pm 0.0^{\mathrm{b}}$ & $0.2 \pm 0.0^{\mathrm{c}}$ & $0.3 \pm 0.0^{\mathrm{a}}$ & $0.3 \pm 0.0^{\mathrm{a}}$ & $0.2 \pm 0.0^{\mathrm{b}}$ \\
\hline $18: 4 n-3$ & $0.9 \pm 0.1^{\mathrm{a}}$ & $0.6 \pm 0.2^{\mathrm{a}}$ & $0.3 \pm 0.0^{\mathrm{b}}$ & $0.3 \pm 0.0^{\mathrm{a}}$ & $0.3 \pm 0.0^{\mathrm{a}}$ & $0.2 \pm 0.0^{\mathrm{b}}$ \\
\hline $20: 4 n-3$ & $0.5 \pm 0.0^{\mathrm{a}}$ & $0.3 \pm 0.0^{\mathrm{b}}$ & $0.2 \pm 0.0^{\mathrm{b}}$ & $0.3 \pm 0.0^{\mathrm{a}}$ & $0.2 \pm 0.0^{\mathrm{b}}$ & $0.2 \pm 0.0^{\mathrm{b}}$ \\
\hline $20: 5 n-3$ & $6.1 \pm 0.4^{\mathrm{b}}$ & $7.8 \pm 0.7^{\mathrm{a}}$ & $5.7 \pm 0.4^{\mathrm{b}}$ & $5.3 \pm 0.2^{\mathrm{c}}$ & $7.6 \pm 0.3^{\mathrm{a}}$ & $6.5 \pm 0.2^{\mathrm{b}}$ \\
\hline $22: 5 n-3$ & $2.1 \pm 0.2^{\mathrm{a}}$ & $2.1 \pm 0.2^{\mathrm{a}}$ & $0.8 \pm 0.0^{\mathrm{b}}$ & $1.6 \pm 0.1^{\mathrm{a}}$ & $1.5 \pm 0.2^{\mathrm{ab}}$ & $1.2 \pm 0.0^{\mathrm{b}}$ \\
\hline $22: 6 n-3$ & $15.1 \pm 1.3^{\mathrm{b}}$ & $27.0 \pm 0.8^{\mathrm{a}}$ & $28.8 \pm 0.9^{\mathrm{a}}$ & $28.3 \pm 0.3^{b}$ & $31.9 \pm 0.8^{\mathrm{a}}$ & $31.2 \pm 0.5^{\mathrm{a}}$ \\
\hline Total n-3 PUFA ${ }^{4}$ & $27.1 \pm 2.0^{\mathrm{b}}$ & $39.6 \pm 0.2^{\mathrm{a}}$ & $37.5 \pm 1.3^{\mathrm{a}}$ & $37.6 \pm 0.2^{\mathrm{b}}$ & $42.7 \pm 2.2^{\mathrm{a}}$ & $40.7 \pm 1.8^{\mathrm{a}}$ \\
\hline C16 PUFA & $2.4 \pm 0.1^{\mathrm{a}}$ & $1.7 \pm 0.0^{\mathrm{b}}$ & $2.6 \pm 0.1^{\mathrm{a}}$ & $2.0 \pm 0.1^{\mathrm{a}}$ & $2.0 \pm 0.0^{\mathrm{b}}$ & $2.4 \pm 0.1^{\mathrm{a}}$ \\
\hline Total PUFA & $38.4 \pm 2.3^{\mathrm{b}}$ & $45.4 \pm 0.4^{\mathrm{a}}$ & $44.4 \pm 1.8^{\mathrm{a}}$ & $45.8 \pm 1.3$ & $48.3 \pm 2.4$ & $47.3 \pm 1.9$ \\
\hline DHA/EPA & $2.5 \pm 0.1^{\mathrm{c}}$ & $3.5 \pm 0.4^{\mathrm{b}}$ & $5.1 \pm 0.2^{\mathrm{a}}$ & $5.3 \pm 0.1^{\mathrm{a}}$ & $4.2 \pm 0.1^{\mathrm{c}}$ & $4.8 \pm 0.1^{b}$ \\
\hline$n-3 / n-6$ & $2.4 \pm 0.1^{\mathrm{c}}$ & $6.9 \pm 0.3^{\mathrm{a}}$ & $5.5 \pm 0.3^{\mathrm{b}}$ & $4.6 \pm 0.2^{\mathrm{c}}$ & $7.6 \pm 0.2^{\mathrm{a}}$ & $6.2 \pm 0.3^{\mathrm{b}}$ \\
\hline Unknown & $3.4 \pm 0.3^{\mathrm{b}}$ & $4.7 \pm 0.2^{\mathrm{a}}$ & $4.7 \pm 0.4^{\mathrm{a}}$ & $3.3 \pm 0.2^{\mathrm{ab}}$ & $3.1 \pm 0.2^{\mathrm{b}}$ & $4.7 \pm 0.3^{\mathrm{a}}$ \\
\hline
\end{tabular}

Results are means \pm SD $(n=2)$. An SD of 0.0 implies an SD of $<0.05$. Mean values, within the same dietary trial, bearing different superscript letters are significantly different $(P<0.05) .{ }^{1}$ Totals include 15:0, 20:0, 22:0, and 24:0. ${ }^{2}$ Totals include 16:1n-9, 18:1n-11, 20:1n $-7,22: 1$ isomers, and $24: 1 .{ }^{3}$ Totals include $18: 3 n-6,20: 2 n-6$, and 22:4n-6. ${ }^{4}$ Totals include 20:3n-3 and 22:3n-3

DHA docosahexaenoic acid, EPA eicosapentaenoic acid, MGK Magokoro, MUFA monounsaturated fatty acid, PUFA polyunsaturated fatty acid, SFA saturated fatty acid, $15 \mathrm{KO}$ diet containing $15 \%$ lipid as krill oil, $20 \mathrm{KO}$ diet containing $20 \%$ lipid as krill oil, $15 \mathrm{KORO}$ diet containing $15 \%$ lipid as $50 \%$ krill oil and $50 \%$ rapeseed oil

whereas fish fed diet MGK had the highest monoene and n-6 PUFA contents (Table 5). In trial B, proportions of $n-3$ PUFA and saturates were highest in muscle of fish fed diet $15 \mathrm{KO}$, whereas muscle of these fish showed the lowest percentages of MUFA and n-6 PUFA (Table 6). Fish fed MGK had the highest content of EPA although no differences were observed in DHA levels among fish fed the different diets in trial $\mathrm{B}$.
Gene transcript abundance in liver

Transcript abundance of lipid metabolism genes in liver of juvenile $A B T$

The transcript abundance of fas in liver of ABT juveniles was significantly higher in fish fed the experimental diets compared to fish fed the reference diet in both trials, although the response was quantitatively lower in trial 
Table 6 Lipid contents (\% of wet weight) and fatty acid compositions (\% of total fatty acids) of liver and muscle from juvenile Atlantic bluefin tuna (Thunnus thynnus L.) fed either a reference diet (Magokoro®), $15 \%$ lipid diet based on krill oil (15KO), or $15 \%$ total lipid diet based on krill oil and rapeseed oil 1:1 $(15 \mathrm{KORO})$ in trial $\mathrm{B}$

\begin{tabular}{|c|c|c|c|c|c|c|}
\hline & \multicolumn{3}{|l|}{ Liver } & \multicolumn{3}{|l|}{ Muscle } \\
\hline & MGK & $15 \mathrm{KO}$ & $15 \mathrm{KORO}$ & MGK & $15 \mathrm{KO}$ & $15 \mathrm{KORO}$ \\
\hline Total lipid (\%) & $10.0 \pm 1.0^{\mathrm{a}}$ & $3.7 \pm 2.2^{\mathrm{b}}$ & $5.4 \pm 1.9^{\mathrm{b}}$ & $0.9 \pm 0.0$ & $0.9 \pm 0.0$ & $0.9 \pm 0.3$ \\
\hline $14: 0$ & $3.3 \pm 0.1^{\mathrm{a}}$ & $2.4 \pm 0.4^{\mathrm{b}}$ & $1.5 \pm 0.4^{\mathrm{c}}$ & $1.2 \pm 0.4^{\mathrm{a}}$ & $1.4 \pm 0.3^{\mathrm{a}}$ & $0.8 \pm 0.1^{\mathrm{b}}$ \\
\hline $16: 0$ & $17.2 \pm 0.6^{\mathrm{ab}}$ & $19.7 \pm 0.7^{\mathrm{a}}$ & $14.8 \pm 2.3^{\mathrm{b}}$ & $18.8 \pm 1.1$ & $20.8 \pm 0.3$ & $18.1 \pm 0.3$ \\
\hline $18: 0$ & $5.5 \pm 0.4$ & $5.6 \pm 0.9$ & $5.6 \pm 0.7$ & $9.7 \pm 0.8^{\mathrm{a}}$ & $9.4 \pm 0.2^{\mathrm{ab}}$ & $8.8 \pm 0.1^{\mathrm{b}}$ \\
\hline Total SFA ${ }^{1}$ & $27.2 \pm 1.0^{\mathrm{ab}}$ & $29.4 \pm 0.8^{\mathrm{a}}$ & $23.3 \pm 2.5^{\mathrm{b}}$ & $31.5 \pm 1.3^{\mathrm{ab}}$ & $33.4 \pm 0.9^{\mathrm{a}}$ & $29.5 \pm 0.5^{\mathrm{b}}$ \\
\hline $16: 1 n-7$ & $4.3 \pm 0.2^{\mathrm{a}}$ & $3.4 \pm 0.5^{\mathrm{ab}}$ & $2.0 \pm 0.5^{\mathrm{b}}$ & $1.6 \pm 0.3^{\mathrm{a}}$ & $1.6 \pm 0.1^{\mathrm{a}}$ & $0.9 \pm 0.1^{\mathrm{b}}$ \\
\hline $18: 1 n-9$ & $16.1 \pm 0.9^{\mathrm{b}}$ & $10.5 \pm 1.1^{\mathrm{c}}$ & $23.7 \pm 4.3^{\mathrm{a}}$ & $9.8 \pm 0.2^{\mathrm{b}}$ & $7.8 \pm 0.5^{\mathrm{c}}$ & $14.4 \pm 1.0^{\mathrm{a}}$ \\
\hline $18: 1 n-7$ & $4.0 \pm 0.2^{\mathrm{b}}$ & $5.2 \pm 0.6^{\mathrm{a}}$ & $4.3 \pm 0.2^{\mathrm{b}}$ & $2.9 \pm 0.1^{\mathrm{c}}$ & $3.8 \pm 0.3^{\mathrm{a}}$ & $3.2 \pm 0.0^{\mathrm{b}}$ \\
\hline $20: 1 n-9$ & $1.9 \pm 0.1^{\mathrm{a}}$ & $1.2 \pm 0.1^{\mathrm{b}}$ & $1.4 \pm 0.3^{\mathrm{ab}}$ & $0.9 \pm 0.0$ & $0.8 \pm 0.0$ & $1.1 \pm 0.1$ \\
\hline Total MUFA ${ }^{2}$ & $30.8 \pm 1.6^{\mathrm{a}}$ & $22.2 \pm 2.4^{\mathrm{b}}$ & $33.4 \pm 5.3^{\mathrm{a}}$ & $18.3 \pm 0.4^{\mathrm{a}}$ & $15.1 \pm 0.2^{\mathrm{b}}$ & $20.8 \pm 1.4^{\mathrm{a}}$ \\
\hline $18: 2 n-6$ & $7.4 \pm 0.4^{\mathrm{a}}$ & $2.2 \pm 0.3^{\mathrm{b}}$ & $7.5 \pm 1.3^{\mathrm{a}}$ & $3.9 \pm 0.1^{\mathrm{b}}$ & $1.6 \pm 0.1^{\mathrm{c}}$ & $4.5 \pm 0.2^{\mathrm{a}}$ \\
\hline $20: 4 n-6$ & $1.5 \pm 0.1^{\mathrm{a}}$ & $1.0 \pm 0.2^{\mathrm{b}}$ & $1.1 \pm 0.3^{\mathrm{ab}}$ & $1.9 \pm 0.2^{\mathrm{a}}$ & $1.1 \pm 0.0^{\mathrm{b}}$ & $1.2 \pm 0.1^{\mathrm{b}}$ \\
\hline $22: 5 n-6$ & $0.7 \pm 0.1^{\mathrm{a}}$ & $0.9 \pm 0.1^{\mathrm{a}}$ & $0.4 \pm 0.2^{\mathrm{b}}$ & $1.1 \pm 0.1^{\mathrm{a}}$ & $0.6 \pm 0.1^{\mathrm{b}}$ & $0.6 \pm 0.0^{\mathrm{b}}$ \\
\hline Total n-6 PUFA ${ }^{3}$ & $11.6 \pm 0.6^{\mathrm{a}}$ & $6.3 \pm 0.2^{\mathrm{b}}$ & $11.0 \pm 1.2^{\mathrm{a}}$ & $9.3 \pm 0.5^{\mathrm{a}}$ & $5.9 \pm 0.2^{\mathrm{b}}$ & $8.6 \pm 0.1^{\mathrm{a}}$ \\
\hline $18: 3 n-3$ & $1.0 \pm 0.0^{\mathrm{b}}$ & $0.6 \pm 0.1^{\mathrm{c}}$ & $1.9 \pm 0.5^{\mathrm{a}}$ & $0.4 \pm 0.0^{\mathrm{b}}$ & $0.3 \pm 0.0^{\mathrm{b}}$ & $1.0 \pm 0.2^{\mathrm{a}}$ \\
\hline $18: 4 n-3$ & $1.1 \pm 0.0^{\mathrm{a}}$ & $1.0 \pm 0.1^{\mathrm{a}}$ & $0.5 \pm 0.2^{\mathrm{b}}$ & $0.4 \pm 0.1^{\mathrm{a}}$ & $0.4 \pm 0.0^{\mathrm{a}}$ & $0.2 \pm 0.0^{\mathrm{b}}$ \\
\hline $20: 4 n-3$ & $0.6 \pm 0.0^{\mathrm{a}}$ & $0.3 \pm 0.0^{\mathrm{b}}$ & $0.2 \pm 0.1^{b}$ & $0.3 \pm 0.0^{\mathrm{a}}$ & $0.2 \pm 0.0^{\mathrm{b}}$ & $0.2 \pm 0.0^{\mathrm{b}}$ \\
\hline $20: 5 n-3$ & $6.6 \pm 0.3^{b}$ & $9.0 \pm 0.3^{\mathrm{a}}$ & $5.3 \pm 0.2^{\mathrm{c}}$ & $5.9 \pm 0.1^{\mathrm{b}}$ & $8.1 \pm 0.2^{\mathrm{a}}$ & $6.1 \pm 0.2^{\mathrm{b}}$ \\
\hline $22: 5 n-3$ & $2.4 \pm 0.2^{\mathrm{a}}$ & $2.0 \pm 0.2^{\mathrm{a}}$ & $1.4 \pm 0.3^{\mathrm{b}}$ & $1.8 \pm 0.0^{\mathrm{a}}$ & $1.5 \pm 0.1^{\mathrm{b}}$ & $1.5 \pm 0.0^{\mathrm{b}}$ \\
\hline $22: 6 n-3$ & $13.7 \pm 0.6^{\mathrm{b}}$ & $23.5 \pm 2.3^{\mathrm{a}}$ & $15.4 \pm 4.2^{\mathrm{b}}$ & $26.9 \pm 1.2$ & $28.2 \pm 1.7$ & $27.6 \pm 1.5$ \\
\hline Total n-3 PUFA ${ }^{4}$ & $26.9 \pm 1.3^{\mathrm{b}}$ & $37.6 \pm 1.9^{\mathrm{a}}$ & $25.5 \pm 3.2^{\mathrm{b}}$ & $37.1 \pm 2.4^{\mathrm{b}}$ & $39.8 \pm 1.3^{\mathrm{a}}$ & $37.5 \pm 1.6^{\mathrm{b}}$ \\
\hline C16 PUFA & $2.3 \pm 0.2$ & $2.0 \pm 0.1$ & $2.0 \pm 0.1$ & $2.5 \pm 0.2^{\mathrm{a}}$ & $2.6 \pm 0.1^{\mathrm{a}}$ & $2.3 \pm 0.1^{\mathrm{b}}$ \\
\hline Total PUFA & $38.5 \pm 1.9^{\mathrm{b}}$ & $43.8 \pm 1.7^{\mathrm{a}}$ & $36.4 \pm 2.2^{\mathrm{b}}$ & $16.5 \pm 2.9$ & $45.7 \pm 1.0$ & $46.0 \pm 1.6$ \\
\hline DHA/EPA & $2.1 \pm 0.0^{\mathrm{b}}$ & $2.6 \pm 0.3^{\mathrm{a}}$ & $2.9 \pm 0.7^{\mathrm{a}}$ & $4.5 \pm 0.3^{\mathrm{a}}$ & $3.5 \pm 0.2^{\mathrm{b}}$ & $4.5 \pm 0.2^{\mathrm{a}}$ \\
\hline$n-3 / n-6$ & $2.3 \pm 0.0^{\mathrm{b}}$ & $6.0 \pm 0.5^{\mathrm{a}}$ & $2.4 \pm 0.5^{\mathrm{b}}$ & $4.0 \pm 0.1^{\mathrm{b}}$ & $6.7 \pm 0.5^{\mathrm{a}}$ & $4.4 \pm 0.2^{\mathrm{b}}$ \\
\hline Unknown & $3.5 \pm 0.2^{\mathrm{c}}$ & $4.6 \pm 0.3^{b}$ & $6.9 \pm 0.3^{\mathrm{a}}$ & $3.7 \pm 0.2^{\mathrm{b}}$ & $5.8 \pm 0.4^{\mathrm{a}}$ & $3.7 \pm 0.4^{\mathrm{b}}$ \\
\hline
\end{tabular}

Results are means $\pm \mathrm{SD}(n=2)$. An SD of 0.0 implies an $\mathrm{SD}$ of $<0.05$. Mean values within the same dietary trial bearing different superscript letters are significantly different $(P<0.05) .{ }^{1}$ Totals include 15:0, 20:0, 22:0, and 24:0. ${ }^{2}$ Totals include 16:1n-9, 18:1n-11, 20:1n-7, 22:1 isomers, and $24: 1 .{ }^{3}$ Totals include $18: 3 n-6,20: 2 n-6$, and 22:4n-6. ${ }^{4}$ Totals include 20:3n-3 and 22:3n-3

DHA docosahexaenoic acid, EPA eicosapentaenoic acid, MGK Magokoro, MUFA monounsaturated fatty acid, PUFA polyunsaturated fatty acid, SFA saturated fatty acid, $15 \mathrm{KO}$ diet containing $15 \%$ total lipid as krill oil, $20 \mathrm{KO}$ diet containing $20 \%$ total lipid as krill oil, $15 \mathrm{KORO}$ diet containing $15 \%$ total lipid as $50 \%$ krill oil and $50 \%$ rapeseed oil

B (Fig. 1). Concerning LC-PUFA biosynthesis genes, in trial A, fads2d6 transcript abundance was significantly higher in fish fed diet $15 \mathrm{KO}$ whereas no differences were observed between fish fed the other two diets (Fig. 1). In contrast, elovl5 transcript abundance was highest in fish fed diet MGK, with abundance in fish fed diet 20KO (with the highest level of dietary DHA and total $n-3$ PUFA) significantly lower than that in fish fed diet $15 \mathrm{KO}$. On the other hand, in trial B, fads $2 d 6$ transcript abundance was significantly higher in fish fed $15 \mathrm{KORO}$ (lowest dietary DHA and total n-3 PUFA contents), whereas no significant differences in abundance were observed between fish fed diet $15 \mathrm{KO}$ compared to fish fed MGK (Fig. 1). Transcript abundance of elovl5 was highest in fish fed diet $15 \mathrm{KO}$ (highest DHA and total $\mathrm{n}-3$ PUFA contents), but no significant differences in abundance of transcripts in this gene were observed between fish fed 15KORO and MGK (Fig. 1). 
fas

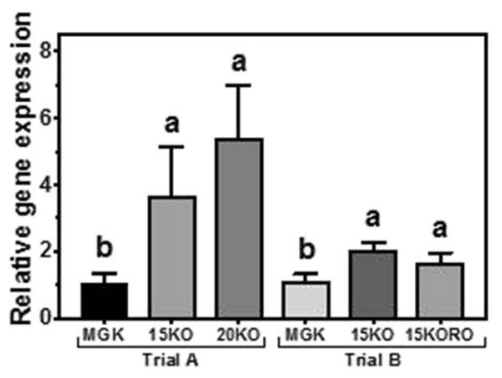

Fig. 1 Nutritional regulation of fatty acid synthase (fas), delta-6 fatty acyl desaturase $(f a d s 2 d 6)$ and fatty acyl elongase 5 (elovl5) gene transcription in liver of Atlantic bluefin tuna (Thunnus thynnus L.) juveniles fed in dietary trial $\mathrm{A}$, a reference diet Magokoro® (MGK), b 15\% lipid diet based on krill oil (15KO), and c $20 \%$ lipid diet based on krill oil (20KO); and in dietary trial

In trial A, hepatic cpt1 transcript abundance was significantly higher in fish fed diet 20KO (highest dietary total lipid, DHA, and total n-3 PUFA), whereas abundance in fish fed diet $15 \mathrm{KO}$ was lower and not significantly different from that of fish fed MGK (Fig. 2). In contrast, in trial B, the pattern was inverted, with hepatic transcript abundance of cpt1 in fish fed diets $15 \mathrm{KO}$ and $15 \mathrm{KORO}$ similar and lower compared to fish fed the MGK diet. Nutritional regulation of the transcript abundance of peroxisomal aco showed a similar pattern in both trials. In trial A, fish fed diets $15 \mathrm{KO}$ and $20 \mathrm{KO}$ showed a significant downregulation compared to fish fed MGK, with no difference between the

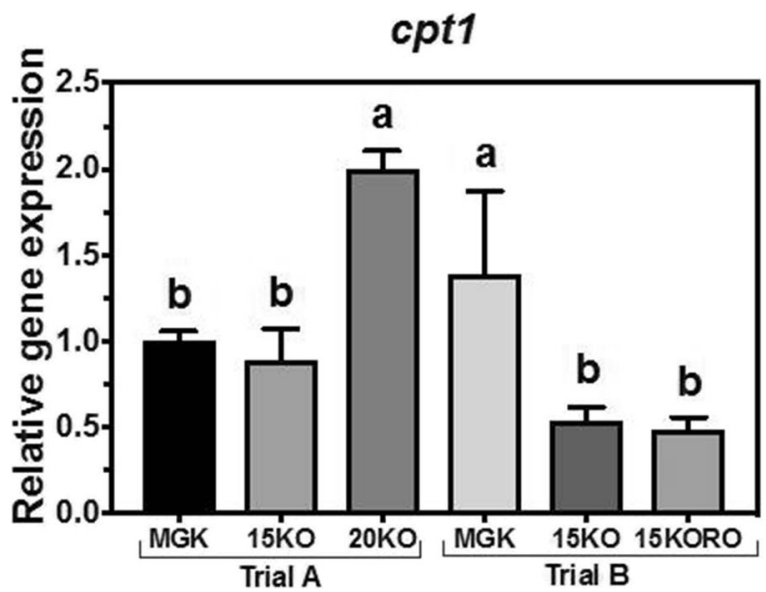

Fig. 2 Nutritional regulation of carnitine palmitoyl transferase I (cptI) and acyl coA oxidase (aco) gene transcription in liver of Atlantic bluefin tuna (Thunnus thynnus L.) juveniles fed in dietary trial A, a reference diet Magokoro ${ }^{\circledR}$ (MGK), b 15\% lipid diet based on krill oil (15KO), and c $20 \%$ lipid diet based on krill oil $(20 \mathrm{KO})$; and in dietary trial $\mathrm{B}$, a reference diet Magokoro ${ }^{\circledR}$ fad2d6

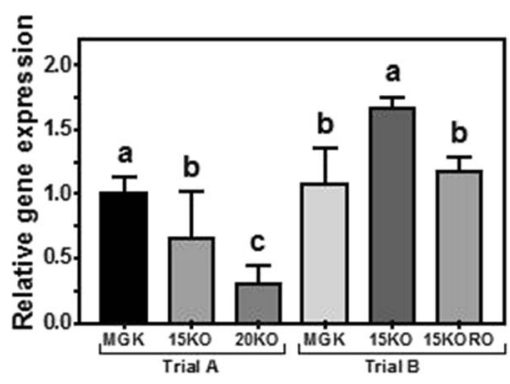

B, a Magokoro® (MGK) reference, b $15 \%$ lipid diet based on krill oil (15KO), and $\mathbf{c} 15 \%$ lipid diet based on krill oil and rapeseed oil $1: 1 ; v / \mathrm{v}(15 \mathrm{KORO})$. Values are normalized expression ratios (to MGK reference diets in trials $\mathrm{A}$ and $\mathrm{B}$ ) and are means $\pm \mathrm{SD}$ of 6 individuals $(n=6)$. Values with different superscript letters are significantly different (one-way ANOVA and Tukey test; $P<0.05$ )

test diets. Similar results were shown in trial B (both test diets downregulated compared to MGK) but, in this case, the transcript abundance in fish fed diet 15KORO was significantly lower than that in fish fed diet $15 \mathrm{KO}$ (Fig. 2).

The nutritional regulation of liver genes related to fatty acid transport ( $f a b p 2$ and $f a b p 4$ ), lipid deposition $(l p l)$, and mitochondrial lipid catabolism $(\mathrm{hmgcl})$ is shown in Fig. 3. In trial A, fabp2 transcript abundance was significantly higher in fish fed $15 \mathrm{KO}$ with no differences between fish fed MGK and 20KO. In trial B, a similar pattern was shown but, in this case, the transcript expression of

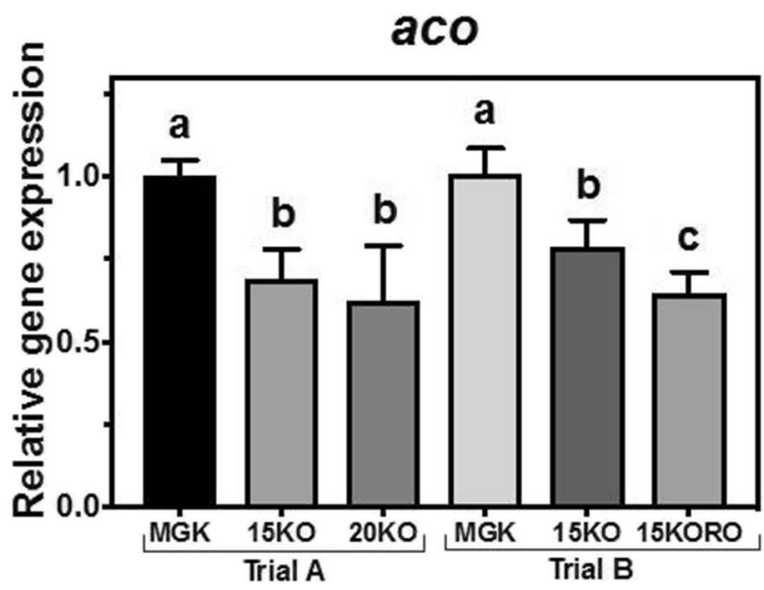

(MGK), b $15 \%$ lipid diet based on krill oil (15KO), and c $15 \%$ lipid diet based on krill oil and rapeseed oil $1: 1 ; v / v$ (15KORO). Values are normalized expression ratios (to MGK reference diets in trials $\mathrm{A}$ and $\mathrm{B})$ and are means $\pm \mathrm{SD}$ of 6 individuals $(n=6)$. Values with different superscript letters are significantly different (one-way ANOVA and Tukey test; $P<0.05$ ) 

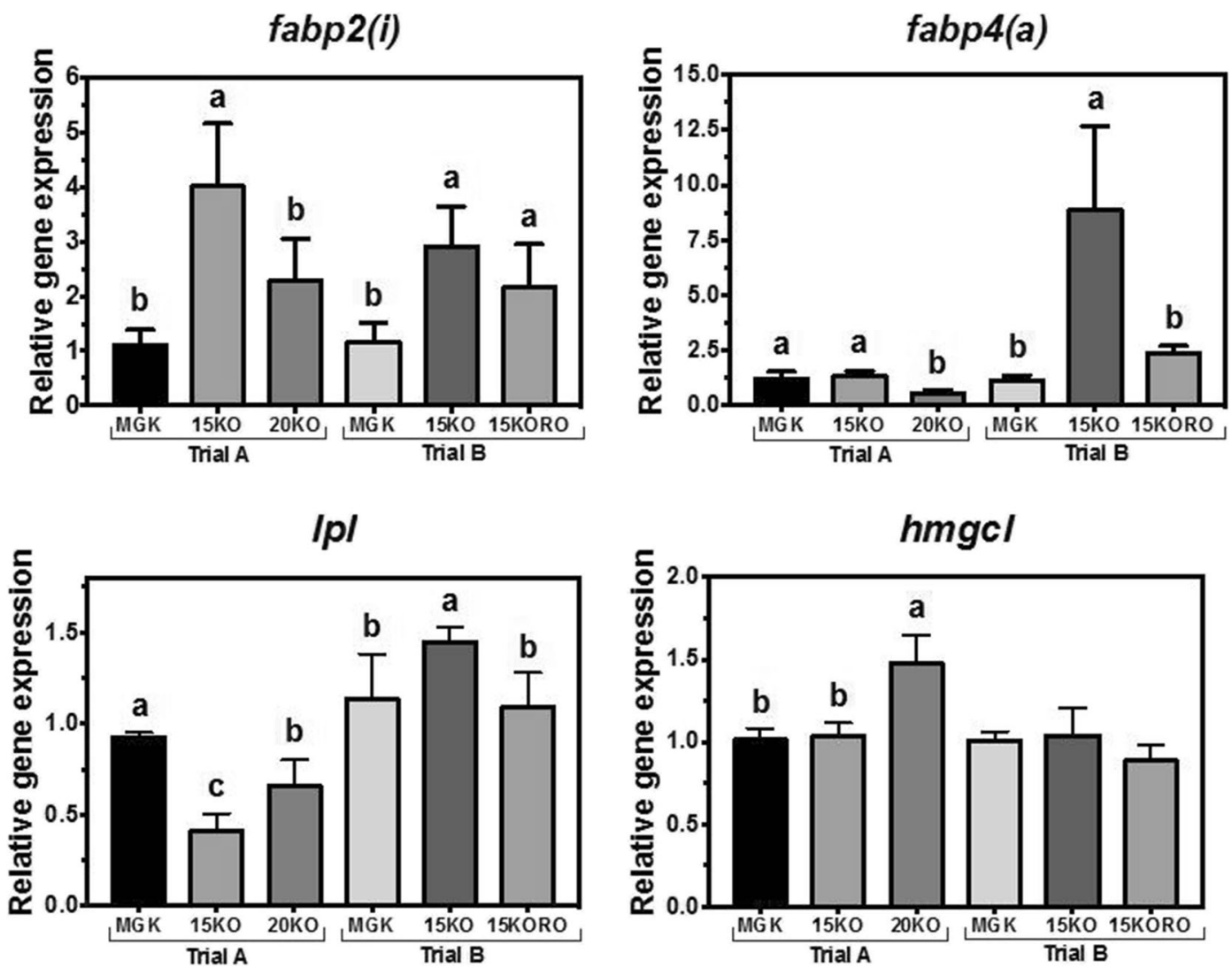

Fig. 3 Nutritional regulation of fatty acid binding protein 2 and 4 (fabp2 and $f a b p 4$, respectively), lipoprotein lipase (lpl), and 3hydroxy-3-methylglutaryl-CoA lyase $(\mathrm{hmgcl})$ gene transcription in liver of Atlantic bluefin tuna (Thunnus thynnus L.) juveniles fed in dietary trial A, a reference diet Magokoro® (MGK), b 15\% lipid diet based on krill oil (15KO), and $\mathbf{c} 20 \%$ lipid diet based on krill oil (20KO); and in dietary trial B, a reference diet Magokoro ${ }^{\circledR}$

fabp2 in liver of fish fed both test diets (15KO and $15 \mathrm{KORO}$ ) was significantly higher compared to fish fed MGK. The transcript abundance of fabp 4 in trial A was significantly lower in liver of fish fed diet $20 \mathrm{KO}$ compared to abundance in fish fed diets MGK and $15 \mathrm{KO}$, which were identical. In trial $\mathrm{B}$, the transcript abundance of fabp 4 was significantly higher in fish fed $15 \mathrm{KO}$. The transcript abundance of $l p l$ was lower in fish fed $15 \mathrm{KO}$ and $20 \mathrm{KO}$ compared to fish fed the MGK diet in trial A but, in contrast, $l p l$ transcript abundance in fish fed $15 \mathrm{KO}$ was higher than those fed the other two diets in trial B. The hepatic transcript abundance of hmgcl in trial A was higher in fish fed diet 20KO, whereas in trial B, no significant differences were found among diets for the abundance of transcripts of this gene.

(MGK), b $15 \%$ lipid diet based on krill oil (15KO), and c $15 \%$ lipid diet based on krill oil and rapeseed oil $1: 1 ; v / v$ (15KORO). Values are normalized expression ratios (to MGK reference diets in trials $\mathrm{A}$ and $\mathrm{B})$ and are means $\pm \mathrm{SD}$ of 6 individuals $(n=6)$. Values with different superscript letters are significantly different (one-way ANOVA and Tukey test; $P<0.05$ )

Transcript abundance of transcription factor genes in liver of juvenile $A B T$

In trial A, ppar $\alpha$ did not show any significant differences in the relative transcript abundance among dietary treatments while in trial $\mathrm{B}$, ppar $\alpha$ transcript abundance in fish fed both test treatments $(15 \mathrm{KO}$ and 15KORO) was significantly higher compared to fish fed MGK (Fig. 4). In contrast, abundance of ppar $\gamma$ gene transcript did not show any differences among the dietary treatments in either trial A or B. Abundance of srebpl gene transcripts was highest in fish fed $20 \mathrm{KO}$ in trial $\mathrm{A}$, and in trial B it was lowest in fish fed 15KORO (Fig. 4). In trial A, srebp 2 showed a pattern of transcript abundance similar to that of srebpl and, in trial B, transcript abundance of srebp 2 was highest in liver of fish fed diet $15 \mathrm{KO}$. 

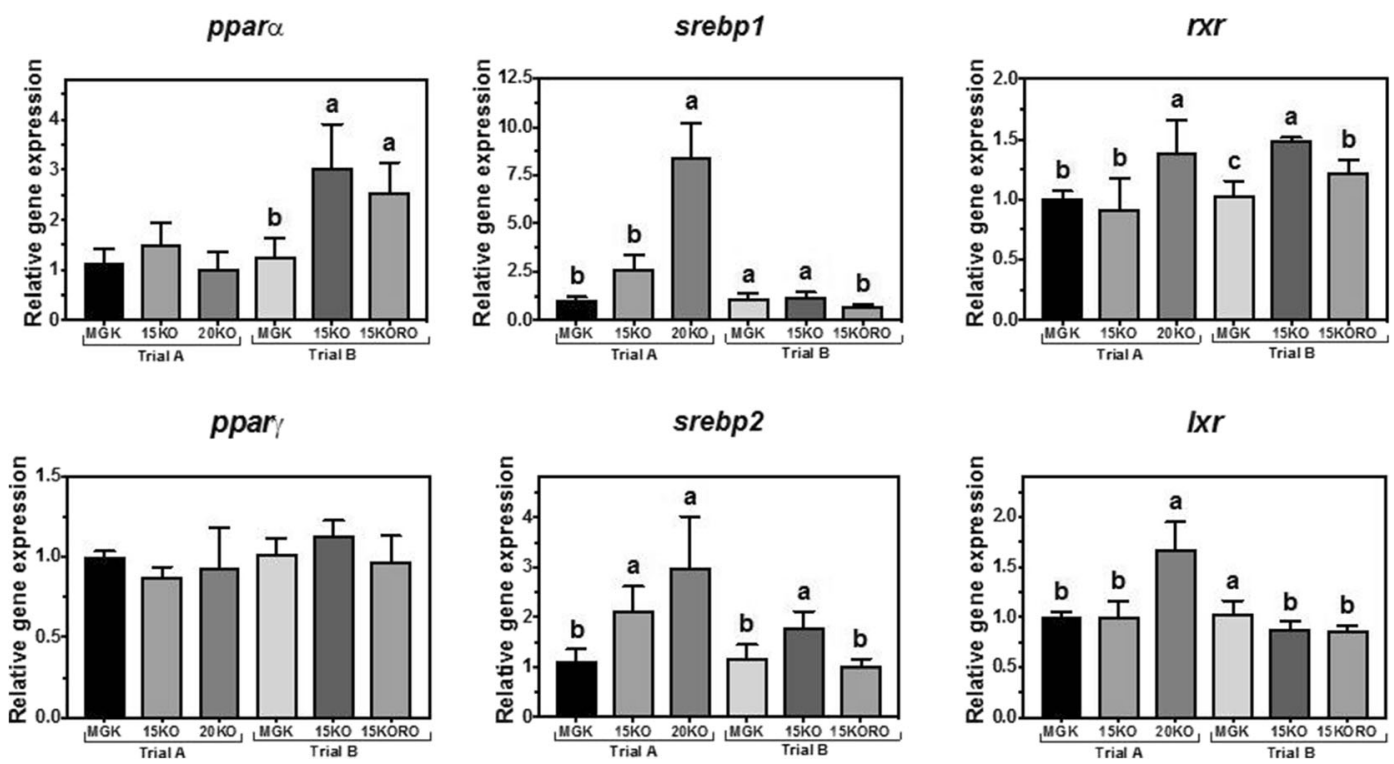

Fig. 4 Nutritional regulation of peroxisome proliferator-activated receptor alpha (ppar $\alpha$ ), gamma (ppar $\gamma)$, sterol regulatory elementbinding protein 1 and 2 (srebpland srebp 2 respectively), retinoid $\mathrm{X}$ receptor $(r x r)$, and liver $\mathrm{X}$ receptor $(l x r)$ gene transcription in liver of Atlantic bluefin tuna (Thunnus thynnus L.) juveniles fed in dietary trial A, a reference diet Magokoro® (MGK), b $15 \%$ lipid diet based on krill oil (15KO), and c $20 \%$ lipid diet based on krill

In trial A, rxr and $l x r$ showed similar patterns of transcript abundance, highest in fish fed diet $20 \mathrm{KO}$ but, in Trial B, rxr transcript abundance was higher in fish fed both test diets compared to MGK, whereas $l x r$ was lower in fish fed $15 \mathrm{KO}$ and $15 \mathrm{KORO}$.

\section{Abundance of transcripts of antioxidant defense enzyme genes}

In trial A, the abundance of sod gene transcripts was higher in fish fed diet 20KO compared to MGK-fed fish while in trial B, sod in fish fed $15 \mathrm{KO}$ was lower than in fish fed MGK (Fig. 5). The transcript abundance of cat was downregulated in response to the test diets in trial $\mathrm{A}$, whereas in trial B fish fed both test diets showed an upregulation of this gene. The patterns of gpxl and gpx4 transcripts abundance were similar in both trials with $g p x 1$ abundance being highest in fish fed $15 \mathrm{KO}$ and abundance of gpx4 being highest in $20 \mathrm{KO}$ and $15 \mathrm{KORO}$ (Fig. 5).

\section{Correlations in transcript abundance}

Some correlations could be established between the transcript abundance of the evaluated genes and other oil (20KO); and in dietary trial $\mathrm{B}$, a reference diet Magokoro® (MGK), b $15 \%$ lipid diet based on krill oil (15KO), and c $15 \%$ lipid diet based on krill oil and rapeseed oil $1: 1 ; v / v$ (15KORO). Values are normalized expression ratios (to MGK reference diets in trials $\mathrm{A}$ and $\mathrm{B})$ and are means $\pm \mathrm{SD}$ of 6 individuals $(n=6)$. Values with different superscript letters are significantly different (one-way ANOVA and Tukey test; $P<0.05$ )

parameters, some of them being common in both trials (Table 7). For example, a strong negative correlation was found between fas gene transcript abundance and liver lipid content, whereas a positive correlation was found between this gene and liver DHA content in both trials. The abundance of transcripts of gpxl and gpx4 was also positively correlated with dietary taurine and Se contents, and hepatic contents of DHA and n-3 PUFA, in both trials. Positive correlations were also found between srebp1 transcript abundance and dietary DHA, dietary n-3 PUFA, fas, and $l x r$ abundance levels in both trials. The transcript abundance of $l x r$ was positively correlated with dietary lipid content in both trials whereas, in contrast, it was positively correlated with fas gene transcript abundance in trial A, but negatively correlated in trial B.

\section{Discussion}

Lipid and protein metabolic pathways dominate intermediary metabolism in carnivorous fish, such as ABT and PBT, as carbohydrate is only a minor component in natural diets in the wild (Tocher 2003; Mourente and 

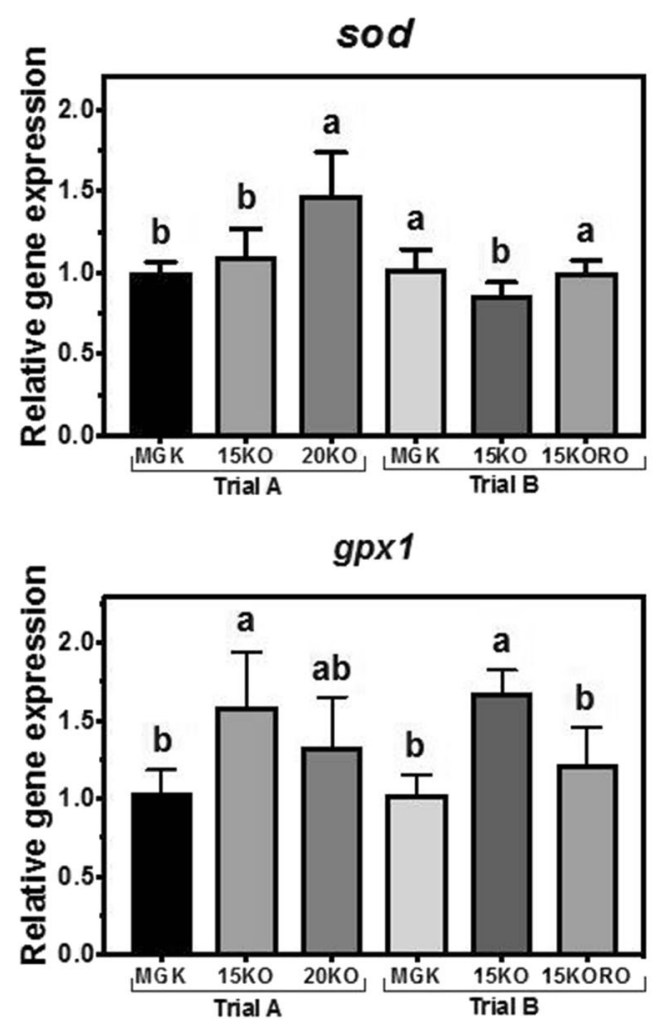

Fig. 5 Nutritional regulation of superoxide dismutase ( $\operatorname{sod}$ ), catalase (cat), and glutathione peroxidase 1 and 4 (gpxl and gpx4, respectively) gene transcription in liver of Atlantic bluefin tuna (Thunnus thynnus L.) juveniles fed in dietary trial A, a reference diet Magokoro® (MGK), b 15\% lipid diet based on krill oil $(15 \mathrm{KO})$, and c $20 \%$ lipid diet based on krill oil $(20 \mathrm{KO})$; and in dietary trial B, a reference diet Magokoro® (MGK), b $15 \%$ lipid

Tocher 2003, 2009). The optimum dietary protein, lipid, and carbohydrate contents have been determined for PBT juveniles (Biswas 2010; Kenji 2012), and it has been suggested that protein and lipid imbalances in formulated diets can result in lower growth performance (Biswas et al. 2009). Results from the trials in the present study indicated that diets with relatively high protein to lipid ratios of between 3 and 4 could support good growth of juvenile ABT.

Availability of appropriate tanks meant that the present study was run as two separate trials rather than one large trial and, serendipitously, this has provided some important insight. While fish more than doubled their weight in both trials, a difference was observed regarding performance of $\mathrm{ABT}$ in the two trials, as fish fed the commercial MGK diet showed higher growth than fish fed the experimental feeds (cf. diet $15 \mathrm{KO}$, which was in both trials) in trial A and lower growth in trial $\mathrm{B}$. While MGK was not specifically formulated for ABT, it was
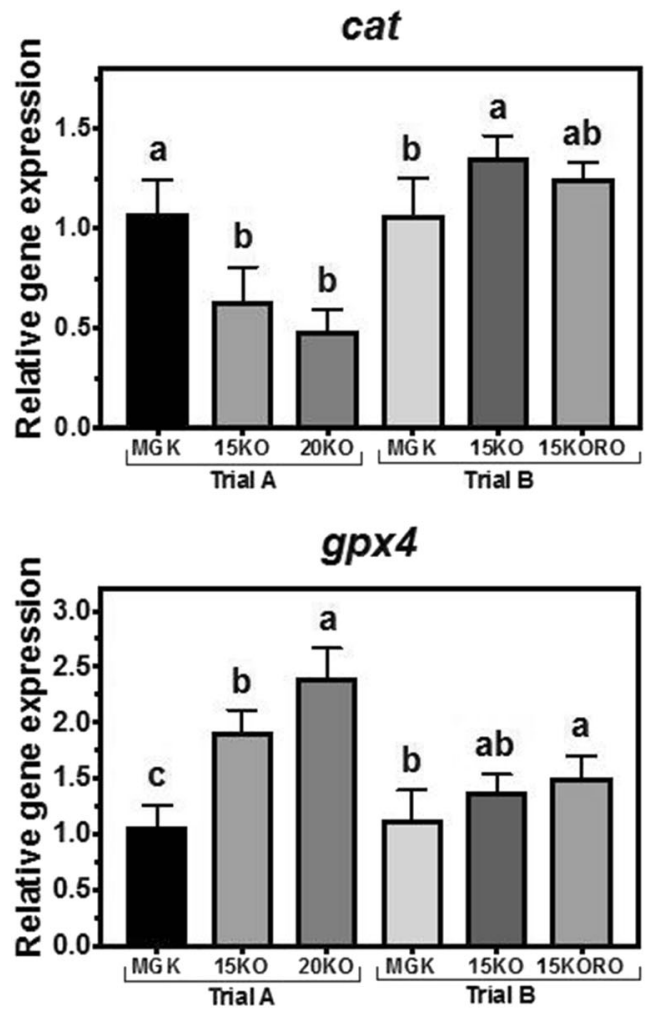

diet based on krill oil (15KO), and $\mathbf{c} 15 \%$ lipid diet based on krill oil and rapeseed oil $1: 1 ; v / v(15 \mathrm{KORO})$. Values are normalized expression ratios (to MGK reference diets in trials $\mathrm{A}$ and $\mathrm{B}$ ) and are means $\pm \mathrm{SD}$ of 6 individuals $(n=6)$. Values with different superscript letters are significantly different (one-way ANOVA and Tukey test; $P<0.05$ )

included in this study as the most appropriate reference diet to provide a benchmark for the performance of the experimental feeds. As such, it is therefore important to acknowledge that it is not a control diet and varied from the experimental feeds in terms of micronutrient contents (see Table 2). In general, in the present study, values measured for growth performance, such as weight gain and SGR, were numerically lower than those observed in trials with PBT juveniles (Biswas 2010; Biswas et al. 2009; Kenji 2012), but similar to those found by Biswas et al. (2011). However, species differences alone cannot explain the differential in performance observed between the two trials. To explain this, it should be noted that the fish used in the two trials were derived from batches of eggs produced at different times in the season from a stock of captive wild broodstock, which could highlight the importance of the genetic background or nutritional status of the broodstock. Indeed, no significant differences were 
Table 7 Correlations established between the expression of the evaluated genes and other parameters.

\begin{tabular}{|c|c|c|}
\hline Correlations & Trial A & Trial B \\
\hline fas/liver lipid content & 0.98 & 0.99 \\
\hline fas/dietary lipid & & 0.95 \\
\hline fas/liver DHA & 0.92 & 0.75 \\
\hline fads $2 s 6 /$ dietary lipid & 0.81 & \\
\hline fads $2 d 6 /$ dietary DHA & & 0.76 \\
\hline fads2d6/dietary PUFA & & 0.80 \\
\hline elovl5/liver lipid & 0.94 & \\
\hline elovl5/dietary DHA & 0.96 & \\
\hline elovl5/liver DHA & & 0.99 \\
\hline elovl5/liver n-3 PUFA & & 0.94 \\
\hline cptI/dietary lipid & & 0.98 \\
\hline cptI/dietary DHA & 0.90 & \\
\hline aco/liver lipid & 0.89 & \\
\hline aco/dietary DHA & & 0.71 \\
\hline aco/dietary n-3 PUFA & & 0.96 \\
\hline aco/ppara & & 0.60 \\
\hline hmgcl/dietary DHA & 0.96 & \\
\hline fabp2/dietary lipid & & 0.90 \\
\hline ppar $/$ liver lipid & & 0.99 \\
\hline ppara/dietary lipid & & 0.97 \\
\hline ppara/cptI & & 0.88 \\
\hline ppara/aco & & 0.60 \\
\hline srebp 1/dietary DHA & 0.99 & 0.99 \\
\hline srebp 1/dietary n-3 PUFA & 0.99 & 0.99 \\
\hline srebpl/fas & 0.82 & 0.02 \\
\hline srebp $1 /$ fads $2 d 6$ & & 0.79 \\
\hline srebp1/elovl5 & 0.90 & \\
\hline srebpl/lxr & 0.95 & 0.16 \\
\hline srebp2/dietary DHA & 0.85 & 0.87 \\
\hline srebp2/dietary n-3 PUFA & 0.89 & 0.74 \\
\hline srebp2/dietary n-3 PUFA & & 0.70 \\
\hline srebp2/liver n-3 PUFA & & 0.53 \\
\hline$l x r /$ dietary lipid & 0.45 & 0.95 \\
\hline$l x r /$ dietary DHA & 0.95 & \\
\hline lxr/dietary n-3 PUFA & 0.97 & \\
\hline lxr/fas & 0.65 & 0.77 \\
\hline sod/dietary DHA & 0.99 & \\
\hline sod/dietary n-3 PUFA & 0.99 & \\
\hline gpx1/liver DHA & 0.67 & 0.98 \\
\hline gpx 1/liver n-3 PUFA & 0.89 & 0.85 \\
\hline gpx4/dietary DHA & 0.82 & \\
\hline gpx4/dietary n-3 PUFA & 0.77 & \\
\hline
\end{tabular}

Green cells indicate positive correlation; red cells represent negative correlation whereas gray cells indicate that no significant correlation was found. The $R^{2}$ value is indicated within each cell Aco acyl coA oxidase, cptI carnitine palmitoyl transferase I, elovl5 fatty acyl elongase 5, fabp 2 fatty acid binding protein 2 (intestinal), fads $2 d 6$ delta- 6 fatty acyl desaturase, fas fatty acid synthase, gpx 1 glutathione peroxidase 1, gpx4 glutathione peroxidase 4, hmgcl 3hydroxy-3-methylglutaryl-CoA lyase, $l x r$ liver $\mathrm{X}$ receptor, ppar $\alpha$ peroxisome proliferator-activated receptor alpha, sod superoxide dismutase, srebpl sterol regulatory element-binding protein 1 , srebp2 sterol regulatory element-binding protein 2 found in relation to feed utilization variables in the trials, which suggests that differences in growth may not be directly or solely related to the feeds themselves. In contrast, it is highly likely that genetic background of the broodstock influenced the data obtained. The difference between the two batches reflects the normal biological variation between individuals and, if different males and, especially, female broodstock contributed to the fertilized eggs in each batch, as is highly likely, the batches would be consequently different. If many different males and females contributed to each batch, then the variation between batches may be less. Therefore, the data suggest that a limited number of individuals contributed to the batches of fertilized eggs and possibly only one female could have spawned each batch of eggs.

Diet had no significant impact on survival partly due to high variability among treatments. However, it is well known, as reported in dietary trials performed with PBT juveniles, that a major part of the mortality at this stage is associated with factors related to stress responses to external stimuli (light, noise, etc.) rather than to dietary deficiencies themselves, in most cases resulting in collisions with the tank wall and often death of the fish (Biswas 2010; Biswas et al. 2009; Cho et al. 2016).

In the present study, neither increased dietary lipid level nor dietary RO increased liver or muscle lipid content. Hepatic lipid deposition is a result of a balance between fatty acid oxidation, synthesis, and transport but, generally, dietary fatty acid composition is reflected in the fish body (Turchini et al. 2009). In the present study, liver fatty acid profiles generally reflected those of diets, as shown previously in other fish studies (Betancor et al. 2014a; Araújo et al. 2017). This clearly indicated that, despite being relatively short, the feeding trials were sufficiently long in these very fast-growing animals to result in the changes in biochemical composition that would be expected in fish that showed a more than doubling of weight. However, levels of fatty acids such as 16:0, 18:0, ARA, and DHA presented slightly higher levels in liver compared to diet, with this more accentuated in liver of fish fed the diet with higher lipid content (20KO in trial A). In contrast, other fatty acids such as 16:1n-7, 18:1n-9, total monoenes, LNA, 18:4n $-3,20: 4 n-3$, EPA, and 22:5n-3 were present in liver at lower percentages than in diet. In addition, liver of fish fed the diet containing vegetable oil (15KORO) showed lower levels of n-3 LC-PUFA, and higher levels of 18:1n-9, LA, and LNA, compared to fish fed the other diets. Higher levels of fatty acids in liver compared to 
feeds are probably due more to selective deposition than to biosynthesis, whereas lower levels in liver may reflect utilization for energy. On the other hand, ABT can be recognized as a lean fish at this fast-growing juvenile stage, and this was reflected in the muscle lipid content, which, in contrast to liver, was very constant and low $(0.8-0.9 \%)$. Similar to several previous studies in other fish species (Bell et al. 2002; Betancor et al. 2014a), the fatty acid profile of juvenile ABT muscle reflected dietary intake and, thus, fish fed the diets containing $\mathrm{KO}$ as the sole added lipid source accumulated high contents of DHA in muscle compared to fish fed the commercial control or KORO feeds. Thus, while using more sustainable feeds containing terrestrial plant ingredients did not impact ABT growth, it can reduce the contents of the health-promoting omega-3 LC-PUFA in their flesh, reducing, in turn, the nutritional value for the consumer.

Generally, upregulation of $f a d s 2 d 6$ expression is observed in fish fed low dietary levels of n-3 LC-PUFA, whereas high dietary levels have been associated with reduced expression (Morais et al. 2012; Betancor et al. 2015a). In the present study, upregulation of fads $2 d 6$ expression was observed in juvenile ABT fed the test diets in relation to the reference diet (primarily in diet $15 \mathrm{KO}$ in trial $\mathrm{A}$ and diet $15 \mathrm{KORO}$ in trial $\mathrm{B}$ ), while no clear pattern was observed in the expression of elovl5, which was downregulated with test diets in trial A and slightly upregulated in $15 \mathrm{KO}$-fed fish in trial $\mathrm{B}$. In a previous trial with ABT larvae (Betancor et al. 2017a), no nutritional regulation of fads $2 d 6$ and elovl5 was observed and the authors hypothesized that this suggested all the diets provided sufficient $n-3$ LC-PUFA to satisfy minimum requirements and thus expression of the genes did not differ. Although differences in the DHA contents of the diets used in the previous trial $\left(13.5-28.3 \mu \mathrm{g} \mathrm{mg}^{-1}\right)$ and the present trial (15.5$29.5 \mu \mathrm{g} \mathrm{mg}^{-1}$ ) were similar, the observed difference in the regulation of the LC-PUFA genes between the studies may indicate an effect of life stage, with different requirements and/or basal biosynthetic activity/ expression in larvae versus juveniles. On the other hand, transcript abundance has not always been shown to correlate with enzyme activity or protein abundance (Maier et al. 2009) that might explain the lack of consistency between the two experiments.

The transcriptional mechanisms that control the synthesis, storage, release, uptake, and oxidation of fatty acids, as the main participants in energy homeostasis, are poorly understood in fish and may vary with fish species (Dong et al. 2017). In fish, as in mammals, two transcription factors (srebp1 and ppar) are implicated in fatty acid biosynthesis and catabolism, respectively (Desvergne et al. 2006; Dong et al. 2017), and their expression can be regulated by dietary fatty acids (Zheng et al. 2009; Minghetti et al. 2011; Dong et al. 2015). Moreover, high dietary levels of n-3 LC-PUFA, including DHA, can act as ligands for transcription factors such as ppar $\alpha$ and srebp1, downregulating the biosynthesis of LC-PUFA (Worgall et al. 1998; Hihi et al. 2002; Cunha et al. 2013; Peng et al. 2014) and regulating the expression of their target genes such as fas, cptI, aco, or lpl. In the present study, srebpl transcript abundance was strongly correlated with those of fas and $l x r$ in both trials. In mammals, it has been shown that srebp 1 expression is stimulated by the expression of lxr (Desvergne et al. 2006), and the results in the present study are also consistent with this. However, previous studies in several fish species showed that srebpl expression was upregulated when feeds contained only low levels of EPA and DHA (Geay et al. 2011; Morais et al. 2011; Betancor et al. 2014a; Limtipsuntorn et al. 2014; Peng et al. 2014). In contrast, in the present study, fish fed the diets with the highest lipid and n-3 LCPUFA contents showed upregulation of both $l x r$ and srebp 1, and srebpl expression was positively correlated to dietary DHA and total n-3 PUFA in both trials. It should be noted that the expression of srebpl, lxr, and fas showed strong positive correlations with dietary DHA and total n-3 PUFA, with weaker responses in trial $\mathrm{B}$ due to the dilution of these components as a result of the inclusion of RO in diet 15KORO. Given the consistency of these results, the up- and downregulation of srebpl and $l x r$ transcript abundance, respectively, in liver of $\mathrm{ABT}$ juveniles might be driven by the decreased/increased lipid accumulation through a feedback mechanism, possibly at post-transcriptional and/or translational levels. On the other hand, $l x r$ acts to regulate the formation of bile acids from cholesterol in mammals (Desvergne et al. 2006) and, in the present study, $l x r$ expression was positively correlated to dietary lipid content, which may be associated with increased synthesis of bile acids to emulsify dietary lipids. Indeed, srebp 2 regulates the expression of genes involved in cholesterol synthesis (Jeon and Osborne 2012; Carmona-Antoñanzas et al. 2014) and is upregulated in response to reduced cholesterol (Minghetti et al. 2011; Carmona-Antoñanzas et al. 2014). In trial A, a 
similar trend of expression was observed between $l x r$ and srebp 2 .

Fatty acids absorbed by liver supply energy through $\beta$-oxidation with ppar $\alpha$ stimulating hepatic $\beta$-oxidation by inducing expression of a set of target genes that participate in many, if not all, aspects of lipid catabolism including key genes cpt1 and aco (Desvergne et al. 2006; Goto et al. 2011). In trial B, the expression of ppar $\alpha$ was negatively correlated to those of $c p t I$ and $a c o$ in response to the test diets, exerting a downregulating effect in fish fed these diets. This may indicate that most dietary lipid was being used by ABT juveniles for membrane biosynthesis during this fast-growing period, with less lipid used for energy production via $\beta$-oxidation, suggesting that most energy was being supplied by the high dietary protein. The transcription factor, ppar $\gamma$, plays important roles in lipogenesis, lipid storage and adipogenesis, and osteogenesis (Nedergaard et al. 2005; Ji et al. 2011; Agawa et al. 2012). However, ppar $\gamma$ showed no regulation in the present study, with no significant differences among dietary treatments in either trial. Similar results were obtained in a 7-day dietary trial with juvenile PBT using test diets formulated with different oil sources, with no differences in ppar $\gamma$ gene expression reported (Agawa et al. 2012). This might indicate that during fast growth of tuna juveniles, increase in biomass prevails over lipid storage, with most of the available dietary resources utilized for anabolic processes and growth.

Fatty acid binding proteins (FABP) are involved in fatty acid uptake, transport, and metabolism (Glatz and van der Vusse 1996), serving as carriers of saturated and unsaturated long-chain fatty acids, eicosanoids, and other hydrophobic ligands to effector molecules in the cytosol and nucleus (Esteves et al. 2015). In the present study, fabp2 gene expression was higher in ABT fed the test diets containing 15\% lipid (15KO and 15KORO) than in the fish fed higher dietary lipid (20KO). In a previous trial, fabp 2 expression was higher when larvae were fed live prey containing $11 \%$ lipid and lower when fed prey with $5.6 \%$ lipid, which could indicate that lipid content regulates expression of this gene in larvae, rather than dietary fatty acid composition (Betancor et al. 2017a). However, Atlantic cod and gilthead sea bream juveniles fed diets containing vegetable oil showed upregulation in the expression of this gene (Lilleeng et al. 2007; Betancor et al. 2016). On the other hand, fabp4 gene expression showed a different pattern, being lower in fish fed diet $20 \mathrm{KO}$ in trial $\mathrm{A}$ and higher in fish fed
$15 \mathrm{KO}$ in trial B. In previous studies in fish, a correlation between $\beta$-oxidation capacity and expression levels of fabps has been suggested (Londraville and Sidell 1996; Torstensen et al. 2009) but, in the present study, no strong correlations between the expression of fabps genes and the expression of genes or transcription factors related to $\beta$-oxidation were observed. The differing expression patterns of different lipid metabolism genes observed between the two trials could be a further influence of genetic background based on the fact that the ABT juveniles came from different spawnings as described above. However, it could also reflect daily rhythms of expression of lipid metabolism genes as has been shown in several teleost species (Betancor et al. 2014b; Hernández-Pérez et al. 2015; Paredes et al. 2015).

In a previous study, $l p l$ was found to be highly expressed in muscle and liver of adult ABT (Betancor et al. 2017b). The $l p l$ gene encodes a lipolytic enzyme responsible for lipid uptake in adipocytes and represents an early marker of adipocyte differentiation. However, studies on the nutritional regulation of $l p l$ expression in fish are scarce. In red sea bream, both feeding conditions and dietary lipid and fatty acid levels were shown to alter $l p l$ expression in liver, with lower expression in fish fed low lipid than in fish fed high lipid (Liang et al. 2002a). In the present study, the expression of $l p l$ in liver of ABT juveniles was low and showed no clear response to diet, similar to previous studies where ABT larvae fed different live prey showed variable $l p l$ expression (Betancor et al. 2017a, b). In contrast, $h m g c l$ expression was upregulated in ABT juveniles fed higher lipid (20KO), while previous studies in larvae did not show any dietary regulation of this gene (Betancor et al. 2017a, b) although increased expression of this enzyme has been associated with enhanced fatty acid oxidation in rat liver (Ide et al. 2009). Therefore, in the present study, the upregulation of $\mathrm{hmgcl}$ in fish fed the higher lipid content could be related to enhanced oxidation of lipids, consistent with the regulation of cpt 1 .

To maintain health and prevent oxidation-induced pathology and mortalities, there must be effective antioxidant systems operating in fish. Enzyme components of antioxidant defense include catalase (CAT), superoxide dismutase (SOD), and glutathione peroxidases (GPX), as well as associated enzymes such as glutathione- $S$-transferase (GST) and glutathione reductase (GR). Lipid peroxidation via ROS is quantitatively the main peroxidative process in mitochondria, damaging 
the membrane lipids. In fish, changes in dietary fatty acid composition can modify mitochondrial membrane composition and alter organelle function leading to an imbalance in oxidative status by affecting the ability to maintain the structural homeostasis of membranes (Betancor et al. 2015b). In the present study, dietary antioxidant protection in terms of antioxidant vitamins, $\mathrm{Se}$, and taurine contents varied between the reference and test diets. Vitamins $\mathrm{E}$ and $\mathrm{C}$ contents were around 5and 2-fold higher in MGK than in the test diets although vitamin $\mathrm{C}$ levels in the test diets could be considered optimal since their values were well above those recommended by Biswas et al. (2013) for juvenile PBT (454 $\mathrm{mg} \mathrm{kg}^{-1}$ diet). In contrast, Se and taurine concentrations were higher in the test feeds than in the reference diet. Taurine has an antioxidant role among other roles (NRC 2011; Salze and Davis 2015) and Se, as a component of the glutathione peroxidase enzyme family, functions as a biological antioxidant (NRC 2011). As stated above, the expression of gpxl and gpx4 were positively correlated with dietary taurine and Se contents in both trials. It could be expected that, if contents of vitamins $\mathrm{E}$ and $\mathrm{C}$ in the test diets were low or insufficient, the liver antioxidant system enzymes of ABT juveniles may compensate to protect from oxidative stress. This could be the situation in some cases where the expression of the genes sod, cat, gpxl, and gpx4 were upregulated in fish fed the test diets (with lower antioxidant vitamins) in comparison to fish fed the reference diet.

In conclusion, the present study suggested that ABT juveniles can be on grown on inert extruded dry feeds with good fish growth and accumulation of the healthpromoting fatty acid DHA. Furthermore, a blend of vegetable and krill oils could be used as the dietary lipid source up to a dietary lipid level of $15 \%$ without affecting fish performance. The expression of lipid metabolism genes in ABT liver showed a different response to dietary lipid level/fatty acid profile consistent with previous data indicating limited n-3 LC-PUFA biosynthetic capability in ABT. However, gene expression sometimes differed between the two trials, which may highlight that genetic background of different batches of ABT juveniles could affect the regulation of metabolic gene expression and thus be a factor in weaning success. The expression of antioxidant enzymes was also altered by diet, related to dietary contents of antioxidant nutrients. Further studies are required in order to fully elucidate lipid and fatty acid requirements of this iconic species in relation to dietary sources and production costs.

Acknowledgments This work was supported by the Programa Estatal de Investigación del Ministerio de Economía y Competitividad del Gobierno de España (Ref. AGL2014-52003C2-1-R, 2014). We wish also thank the technical staff at Laboratory of Marine Aquaculture (IEO), Puerto de Mazarrón (Murcia), Spain and Nutritional Analytical Services (NAS), Institute of Aquaculture, University of Stirling, UK that contributed to this work.

Open Access This article is distributed under the terms of the Creative Commons Attribution 4.0 International License (http:// creativecommons.org/licenses/by/4.0/), which permits unrestricted use, distribution, and reproduction in any medium, provided you give appropriate credit to the original author(s) and the source, provide a link to the Creative Commons license, and indicate if changes were made.

\section{References}

Ackman RG (1980) Fish lipids. In: Connell JJ (ed) Advances in fish science and technology. Fishing News Books, Farnham, pp 83-103

Agawa Y, Honryo T, Ishii A, Kobayashi T, Oku H, Sawada Y (2012) Molecular identification and tissue distribution of peroxisome proliferators activated receptor gamma transcript in cultured Thunnus orientalis. Aquac Res 43:1145-1158

AOAC (2000) Official methods of analysis. Association of Official Analytical Chemists, Washington, DC

Araújo B, Salini M, Glencross B, Wade N (2017) The influence of dietary fatty acid and fasting on the hepatic lipid metabolism of barramundi (Lates calcarifer). Aquac Res 48:3879-3893

Bell JG, Henderson RJ, Tocher DR, McGhee F, Dick JR, Porter A, Smullen RP, Sargent JR (2002) Substituting fish oil with crude palm oil in the diet of Atlantic salmon (Salmo salar) affects muscle fatty acid metabolism and hepatic fatty acid metabolism. J Nutr 132:222-230

Benetti D, Partridge GJ, Buentello A (Eds.) (2016) Advances in tuna aquaculture: from hatchery to market. Academic Press. 376 pp, ISBN 9780124114593

Betancor MB, Caballero MJ, Terova G, Corà S, Saleh R, BenítezSantana T, Bell JG, Hernández-Cruz CM, Izquierdo M (2012a) Vitamin $C$ enhances vitamin $E$ status and reduces oxidative stress indicators in sea bass larvae fed high DHA microdiets. Lipids 47:1193-1207

Betancor MB, Caballero MJ, Terova G, Saleh R, Atalah E, Benítez-Santana T, Bell JG, Izquierdo M (2012b) Selenium inclusion decreases oxidative stress indicators and muscle injuries in sea bass larvae fed high-DHA microdiets. Br J Nutr 13:1-14

Betancor MB, Howarth FJE, Glencross BD, Tocher DR (2014a) Influence of dietary docosahexaenoic acid in combination with other long-chain polyunsaturated fatty acids on 
expression of biosynthesis genes and phospholipid fatty acid compositions in tissues of post-smolt Atlantic salmon (Salmo salar). Comp Biochem Physiol 172-173B:74-898

Betancor MB, McStay E, Minghetti M, Migaud H, Tocher DR, Davie A (2014b) Daily rhythms in expression of genes of hepatic lipid metabolism in Atlantic salmon (Salmo salar L.). PLoS One 9:e106739

Betancor MB, Sprague M, Sayanova O, Usher S, Campbell PJ, Napier JA, Caballero MJ, Tocher DR (2015a) Evaluation of a high-EPA oil from transgenic Camelina sativa in feeds for Atlantic salmon (Salmo salar L.): effects on tissue fatty acid composition, histology and gene expression. Aquaculture 444:1-12

Betancor MB, Almaida-Pagán PF, Hernández A, Tocher DR (2015b) Effects of dietary fatty acids on mitochondrial phospholipid compositions, oxidative status and mitochondrial gene expression of zebrafish at different ages. Fish Physiol Biochem 41:1187-1204

Betancor MB, Sprague M, Montero D, Usher S, Sayanova O, Campbell PJ, Napier JA, Caballero MJ, Izquierdo M, Tocher DR (2016) Replacement of marine fish oil with de novo omega-3 oils from transgenic Camelina sativa in feeds for gilthead sea bream (Sparus aurata). Lipids 51:1171-1191

Betancor MB, Ortega A, de la Gándara F, Tocher DR, Mourente G (2017a) Molecular aspects of lipid metabolism, digestibility and antioxidant status of Atlantic bluefin tuna (T. thynnus L.) larvae during first feeding. Aquaculture 479:357-369

Betancor MB, Ortega A, de la Gándara F, Tocher DR, Mourente G (2017b) Lipid metabolism-related gene expression pattern of Atlantic bluefin tuna (Thunnus thynnus L.) larvae fed on live prey. Fish Physiol Biochem 43:493-516

Bidlingmeyer BA, Cohen SA, Tarvin TL, Frost B (1987) A new, rapid, high sensitivity analysis of amino acids in food type samples. J Assoc Off Anal Chem 70:241-247

Biswas BK (2010) Establishment of formulated diet for rearing juvenile bluefin tuna. Bull fish Lab Kinki Univ 129:71-129

Biswas BK, Ji SC, Biswas AK, Seoka M, Kim YS, Kawasaki K, Takii K (2009) Dietary protein and lipid requirement for the Pacific bluefin tuna Thunnus orientalis juvenile. Aquaculture 288:114-119

Biswas A, Biswas BK, Ito J, Takaoka O, Yagi N, Itoh S, Takii K (2011) Soybean meal can partially replace enzyme-treated fish meal in the diet of juvenile Pacific bluefin tuna Thunnus orientalis. Fish Sci 77:615-621

Biswas BK, Biswas A, Junichi I, Kim YS, Takii K (2013) The optimal dietary level of ascorbic acid for juvenile Pacific bluefin tuna, Thunnus orientalis. Aquac Int 21:327-336

Biswas A, Nakajima M, Nakao T, Takaoka O, Takii K (2016) Determination of suitable protein and lipid levels in diets for Pacific bluefin tuna, Thunnus orientalis at grow-out stage. Aquacult Sci 64:281-288

Carmona-Antoñanzas G, Tocher DR, Martinez-Rubio L, Leaver MJ (2014) Conservation of lipid metabolic gene transcriptional regulatory networks in fish and mammals. Gene 534: $1-9$

Cho J, Haga Y, Kamimura S, Akazawa A, Itoh A, Satoh S (2016) Production performance of Pacific bluefin tuna Thunnus orientalis larvae and juveniles fed commercial diets and effects of switching diets. Aquacult Sci 64:359-370

Christie WW (2003) Lipid analysis, 3rd edn. The Oily Press, Dundee
Cowey CB, Adron JW, Walton MJ, Murray J, Youngson A, Knox D (1981) Tissue distribution, uptake and requirement for atocopherol of rainbow trout (Salmo gairdneri) fed diets with a minimal content of unsaturated fatty acids. J Nutr 111: $1556-1567$

Cunha I, Galante-Oliveira S, Rocha E, Planas M, Urbatzka R, Castro LFC (2013) Dynamics of PPARs, fatty acid metabolism genes and lipid clases in eggs and early larvae of a teleost. Comp Biochem Physiol 164B:247-258

De La Gándara F, Ortega A, Buentello A (2016) Tuna aquaculture in Europe. In: Benetti DD, Partridge GJ, Buentello A (eds) Advances in tuna aquaculture: from hatchery to market. Elsevier AP, New York, pp 273-321

Desvergne B, Michalik L, Wahli W (2006) Transcriptional regulation of metabolism. Physiol Rev 86:465-514

Dong X, Xu H, Mai K, Xu W, Zhang Y, Ai Q (2015) Cloning and characterization of SREBP-1 and PPAR-alpha in Japanese seabass Lateolabrax japonicus, and their gene expressions in response to different dietary fatty acid profiles. Comp Biochem Physiol Biochem Mol Biol 180B:48-56

Dong X, Tan P, Cai Z, Xu H, Li J, Ren W, Xu H, Zuo R, Zhou J, Mai K, Ai Q (2017) Regulation of FADS2 transcription by SREBP-1 and PPAR- $\alpha$ influences LC-PUFA biosynthesis in fish. Sci Rep 7:40024

Esteves A, Knoll-Gellida A, Canclini L, Silvarrey MC, André M, Babin PJ (2015) Fatty acid-binding proteins have the potential to channel dietary fatty acid into enterocyte nuclei. J Lipid Res 57:219-232

Folch J, Lees M, Sloane-Stanley GH (1957) A simple method for the isolation and purification of total lipids from animal tissues. J Biol Chem 226:497-509

Geay F, Ferraresso S, Zambonino-Infante JL, Bargelloni L, Quentel C, Vandeputte M, Kaushik S, Cahu CL, Mazurais D (2011) Effects of the total replacement of fish-based diet with plant-based diet on the hepatic transcriptome of Teo European sea bass (Dicentrarchus labrax) half-sibfamilies showing different growth rates with the plant-based diet. BMC Genomics 12:522

Glatz JF, van der Vusse GJ (1996) Cellular fatty acid-binding proteins: their function and physiological significance. Prog Lipid Res 35:243-282

Glencross BD, De Santis C, Bicskei B, Taggart JB, Bron JE, Betancor MB, Tocher DR (2015) A comparative analysis of the response of the hepatic transcriptome to dietary docosahexaenoic acid in Atlantic salmon (Salmo salar) post-smolts. BMC Genomics 16:1-12

Goto T, Lee JY, Teraminami A, Kim YI, Hirai S, Uemura T, Inoue H, Takahashi N, Kawada T (2011) Activation of peroxisome proliferator-activated receptor-alpha stimulates both differentiation and fatty acid oxidation in adipocytes. J Lipid Res 52: 873-884

Gregory MK, See VHL, Gibson RA, Schuller KA (2010) Cloning and functional characterisation of a fatty acyl elongase from southern bluefin tuna (Thunnus maccoyii). Comp Biochem Physiol 155B:178-185

Hernández-Pérez J, Míguez JM, Libran-Pérez M, Otero-Rodiño C, Naderi F, Soengas JL, López-Patiño MA (2015) Daily rhythms in activity and mRNA abundance of enzymes involved in glucose and lipid metabolism in liver of rainbow trout, Oncorhynchus mykiss. Influence of light and food availability. Chronobiol Int 32:1391-1408 
Hihi AK, Michalik L, Wahli W (2002) PPARs: transcriptional effectors of fatty acids and their derivatives. Cell Mol Life Sci 59:790-798

Hixson SM, Parrish CC, Xue X, Wells JS, Collins SA, Anderson DM, Rise ML (2017) Growth performance, tissue composition and gene expression responses in Atlantic salmon (Salmo salar) fed varying levels of different lipid sources. Aquaculture 467:76-88

Honryo T, Oakada T, Kawahara M, Kurata M, Agawa Y, Sawada Y, Miyashita S, Takii K, Ishibashi Y (2018) Estimated time for recovery from transportation stress and starvation in juvenile Pacific blue fin tuna Thunnus orientalis. Aquaculture 484:175-183

Ide T, Lim JS, Odbayar TO, Nakashima Y (2009) Comparative study of sesame lignans (sesamin, episesamin and sesamolin) affecting gene expression profile and fatty acid oxidation in rat liver. J Nutr Sci Vitaminol 55:31-43

Jeon TI, Osborne TF (2012) SREBPs: metabolic integrators in physiology and metabolism. Trends Endocrinol Metab 23: $65-72$

Ji H, Liu Y, Zhao X, Zhang M (2011) N-acetyl-L-cysteine enhances the osteogenic differentiations and inhibits the adipogenic differentiation through up regulation of Wnt $5 \mathrm{a}$ and down regulation of PPARg in bone marrow stromal cells. Biomed Pharmacother 65:369-374

Kenji T (2012) Formula feed for Pacific bluefin tuna. In: Kumai H, Miyashita S, Sakamoto W, Ono S (eds) Full-life cycle aquaculture of the Pacific bluefin tuna. Agriculture and Forestry Statistics Publishing Inc, Tokyo, p 136

Kurata M, Ishibashi Y, Seoka M, Honryo T, Katayama S, Fukuda H, Takii K, Kumai H, Miyashita S, Sawada Y (2015) Influence of swimbladder inflation failure on mortality, growth and lordotic deformity in Pacific bluefin tuna, Thunnus orientalis, (Temminck \& Schlegel) postflexion larvae and juveniles. Aquac Res 46:1469-1479

Liang XF, Oku H, Ogata HY (2002) The effects of feeding condition and dietary lipid level on lipoprotein lipase gene expression in liver and visceral adipose tissue of red sea bream Pagrus major. Comp Biochem Physiol 131A:335-342

Librán-Pérez M, Geurden I, Dias K, Corraze G, Panserat S, Soengas JL (2015) Feeding rainbow trout with a lipid-enriched diet: effects on fatty acid sensing, regulation of food intake and cellular signaling pathways. J Exp Biol 218:2610-2619

Lilleeng E, Frøystad MK, Vekterud K, Valen EC, Krogdahl $\AA$ (2007) Comparison of intestinal gene expression in Atlantic cod (Gadus morhua) fed standard fish meal or soybean meal by means of suppression subtractive hybridization and realtime PCR. Aquaculture 267:269-283

Limtipsuntorn U, Haga Y, Kondo H, Hirono I, Satoh S (2014) Microarray analysis of hepatic gene expression in juvenile Japanese flounder Paralichthys olivaceus fed diets supplemented with fish or vegetable oils. Mar Biotechnol 16:88102

Londraville RL, Sidell BD (1996) Cold acclimation increase fatty acid-binding protein concentration in aerobic muscle of striped bass, Morone saxatilis. J Exp Zool 175:36-44

Maier T, Güell M, Serrano L (2009) Correlation of nRNA and protein in complex biological samples. FEBS Lett 583:39663973

Martinez-Rubio L, Wadsworth S, González Vecino JL, Bell JG, Tocher DR (2013) Effect of dietary digestible energy content on expression of genes of lipid metabolism and LC-PUFA biosynthesis in liver of Atlantic salmon (Salmo salar L.). Aquaculture 384-387:94-103

McMurray CH, Blanchflower WJ, Rice DA (1980) Influence of extraction techniques on determination of $\alpha$-tocopherol in animal feedstuffs. J Assoc Off Anal Chem 63:1258-1261

Minghetti M, Leaver MJ, Tocher DR (2011) Transcriptional control mechanisms of genes of lipid and fatty acid metabolism in the Atlantic salmon (Salmo salar L.) established cell line, SHK-1. Biochim Biophys Acta - Mol Cell Biol Lipids 1811: 194-202

Miyashita S, Sawada Y, Hottori N, Nakatsukasa H, Okada T, Murata O, Kumai H (2000) Mortality of northern bluefin tuna Thunnus thynnus due to trauma caused by collision during growout culture. J World Aquacult Soc 31:632-639

Morais S, Mourente G, Ortega A, Tocher JA, Tocher DR (2011) Expression of fatty acyl desaturase and elongase genes, and evolution of DHA/EPA ratio during development of unfed larvae of Atlantic bluefin tuna (Thunnus thynnus L.). Aquaculture 313:129-139

Morais S, Castanheira F, Martinez-Rubio L, Conceição LEC, Tocher DR (2012) Long chain polyunsaturated fatty acid synthesis in a marine vertebrate: ontogenetic and nutritional regulation of a fatty acyl desaturase with $\Delta 4$ activity. Biochim Biophys Acta - Mol Cell Biol Lipids 1821:660-671

Mourente G, Tocher DR (2003) An approach to study the nutritional requirements of the bluefin tuna (Thunnus thynnus thynnus L.). Cahiers Options Méditérr 60:143-150

Mourente G, Tocher DR (2009) Tuna nutrition and feeds: current status and future perspectives. Rev Fish Sci 17:374-391

Nedergaard J, Ricquier D, Kozak LP (2005) Uncoupling proteins: current status and therapeutic prospects. EMBO Rep 6:917921

NRC (2011) Nutrient requirements of fish and shrimp. In: National Research Council. Academic Press, Washington DC

Okada T, Honryo T, Sawada Y, Agawa Y, Miyashita S, Ishibashi Y (2014) The cause of death of juvenile Pacific bluefin tuna (Thunnus orientalis) reared in sea net cages. Aquac Eng 59: 23-25

Ortega A (2015) Cultivo Integral de dos especies de escómbridos: Atún rojo del Atlántico (Thunnus thynnus, L. 1758) y Bonito Atlántico (Sarda sarda, Bloch 1793). PhD dissertation, Universidad de Murcia, Murcia (Spain)

Paredes JF, López-Olmeda JF, Martínez FJ, Sánchez-Vázquez FJ (2015) Daily rhythms of lipid metabolic gene expression in zebrafish liver: response to light/dark and feeding cycles. Chronobiol Int 32:1438-1448

Peng M, Xu W, Mai K, Zhou H, Zhang Y, Liufu Z, Zhang K, Ai Q (2014) Growth performance, lipid deposition and hepatic lipid metabolism related gene expression in juvenile turbot (Scophthalmus maximus L.) fed diets with various fish oil substitution levels by soybean oil. Aquaculture 433:442-449

Pfaffl MW, Morgan GW, Dempfle L (2002) Relative expression software tool (REST) for group-wise comparison and statistical analysis of relative expression results in real-time PCR. Nucleic Acids Res 30:e36

Salze GP, Davis DA (2015) Taurine: a critical nutrient for future fish feeds. Aquaculture 437:215-229

Sargent JR, Tocher DR, Bell JG (2002) The lipids. In: Halver JE, Hardy RW (eds) Fish nutrition, 3rd edn. Academic Press Inc, San Diego, pp 182-246 
Scholefield AM, Tocher DR, Schuller KA (2015) Dynamics of fatty acid metabolism in a cell line from southern bluefin tuna (Thunnus maccoyii). Aquaculture 449:58-68

Tocher DR (2003) Metabolism and function of lipids and fatty acids in teleost fish. Rev Fish Sci 11:107-184

Tocher DR (2010) Fatty acid requirements in ontogeny of marine and freshwater fish. Aquac Res 41:717-732

Tocher DR, Harvie DG (1988) Fatty acid composition of the major phosphoglycerides from fish neutral tissues: $(n-3)$ and $(n-6)$ polyunsaturated fatty acids in rainbow trout (Salmo gairdneri L.) and cod (Gadus morhua L.) brains and retinas. Fish Physiol Biochem 5:229-239

Torstensen BE, Nanton D, Olsvik P, Sundvold H, Stubhaug I (2009) Gene expression of fatty acid-binding proteins, fatty acid transport proteins (cd36 and FATP) and $\beta$-oxidationrelated genes in Atlantic salmon (Salmo salar L.) fed fish oil or vegetable oil. Aquac Nutr 15:440-451

Turchini GM, Torstensen BE, Ng WK (2009) Fish oil replacement in finfish nutrition. Rev Aquacult 1:10-57

Van Beijnen J (2017) The closed cycle aquaculture of Atlantic Bluefin Tuna in Europe: current status, market perceptions and future potential. Technical Report, 95p. Available at https://www.researchgate.net/profile/Jonah_Van Beijnen/publication/317663537_The_closed_cycle_ aquaculture_of_Atlantic_Bluefin_Tuna_in_Europe_current status_market_perceptions_and_future perspectives/links/5947e6460f7e9b1d9b22f99c/The-closedcycle-aquaculture-of-Atlantic-Bluefin-Tuna-in-Europecurrent-status-market-perceptions-and-future-perspectives. pdf. Accessed 7 Nov 2018

Worgall TS, Sturley SL, Seo T, Osborne TF, Deckelbaum RJ (1998) Polyunsaturated fatty acids decrease expression of promoters with sterol regulatory elements by decreasing levels of mature sterol regulatory element-binding protein. $\mathrm{J}$ Biol Chem 273:25537-25540

Zar JH (1999) Biostatistical analysis, 4th edn. Prentice-Hall, New Jersey

Zheng X, Leaver MJ, Tocher DR (2009) Long-chain polyunsaturated fatty acid synthesis in fish: comparative analysis of Atlantic salmon (Salmo salar L.) and Atlantic cod (Gadus morhua L.) $\Delta 6$ fatty acyl desaturase gene promoters. Comp Biochem Physiol Biochem Mol Biol 154B:255-263 